\title{
ВНУТРЕННИЙ КОНФЛИКТ ДУАЛЬНОЙ СИМВОЛИКИ ИЛИ КОНФЛИКТ В ОБЩЕСТВЕ: ОБРЯДЫ ПАРНЫХ ЖЕРТВОПРИНОШЕНИЙ ЛОШАДЕЙ В СИНТАШТИНСКИХ И ПЕТРОВСКИХ НЕКРОПОЛЯХ ЮЖНОГО ЗАУРАЛЬЯ И КАЗАХСТАНА
}

\author{
Елена Владиславовна Куприянова \\ Челябинский государственный университет, Челябинск, Россия \\ E-mail: dzdan@mail.ru
}

\begin{abstract}
Аннотация. Взаимное соотношение двух ярких культурных образований бронзового века в степной зоне Евразии - синташтинской и петровской археологических культур, по-прежнему порождает много вопросов и гипотез. На примере детального анализа сходства и различия обрядов парных жертвоприношений лошадей в данных культурах предложена схема интерпретации одного из древних индоевропейских мифологических сюжетов - близнечного мифа - в синташтинском и петровском обществах, отражающая отличия их социальных систем. Основная часть синташтинских парных жертвенников с лошадьми, в том числе с колесничной символикой, приурочена к коллективным погребениям, состоит из «частичных» животных (голов и ног). Основная часть парных жертвенников петровской культуры приурочена к индивидуальным погребениям и представлена целыми тушами лошадей. Можно предположить, что в синташтинском социуме культ лошади и феномен колесничества ассоциировались с определенной группой людей, тогда как в петровском они стали принадлежностью индивидуумов. Колесничная символика сопровождает менее чем половину зафиксированных жертвенников. Второй темой обряда парных жертвоприношений является символика плодородия. Таким образом, в двух данных культурах парные жертвоприношения различаются по характеру и, в то же время, отражают в обеих две противоположные темы - войны/смерти и плодородия/жизни. Этот символический антагонизм соответствует индоевропейскому варианту мифологического сюжета о Божественных близнецах, которые прочно связаны с темой колесничества/всадничества и одновременно воплощают ряд антитез: связь с войной и культами плодородия, лошадь воина и лошадь землепашца, производящую и воинскую функции общества.
\end{abstract}

Ключевые слова: Южное Зауралье, бронзовый век, синташтинская культура, петровская культура, погребальный обряд, парные жертвоприношения лошадей

Цитирование. Куприянова Е.В., 2021. Внутренний конфликт дуальной символики или конфликт в обществе: обряды парных жертвоприношений лошадей в синташтинских и петровских некрополях Южного Зауралья и Казахстана // Уфимский археологический вестник. Т. 21, №2. C. 274-297. DOI: https://doi. org/10.31833/uav/2021.21.2.007

UDC 902/904

Submitted: 26.08 .2021

LBC 63.4

Accepted: 20.10.2021

INTERNAL CONFLICT OF DUAL SYMBOLISM OR THE CONFLICT IN SOCIETY:

PAIRED HORSE SACRIFICES FROM THE NECROPOLISES OF THE SINTACHTA AND PETROVKA CULTURE IN THE SOUTHERN TRANS-URALS AND KAZAKHSTAN

\author{
Elena V. Kupriyanova \\ Chelyabinsk State University, Chelyabinsk, Russia \\ E-mail: dzdan@mail.ru
}

\begin{abstract}
The Sintashta and Petrovka archaeological cultures could be viewed as one of the most famous phenomena of the Bronze Age period in the Eurasian steppe zone and the present day archaeologist are engaged in a series of lively debates over their social structure, origins and interactions with each other. This article contributes new data to the topic, based on the analysis of similarities and differences in the rite of paired horse sacrifices in the Sintashta and Petrovka cultures. It also presents an archaeologically based interpretation of the ancient Indo-European mythological narrative, namely the twin myth. Most of the Sintashta paired horse sacrifices (including those with chariot symbols) accompany collective burials. They contain only some parts of the horse, namely heads and legs. Paired horse sacrifices of the Petrovka culture, by contrast, usually accompany individual burials and contain whole horse carcasses. We suggest that the aforementioned differences reflect key differences in the social systems of two cultures, expressing them in a ritual form. It seems that in the Sintashta society the cult of the horse and charioting were linked to a group of people, while in the Petrovka society these phenomena were associated with the particular individuals. Notably, only about a half of the discovered horse sacrifices contain chariot symbols such as horse harness remains, traces of chariot wheels, ranged weapons, etc. Others contain symbols of fertility. Thus, the paired horse burials in the two analyzed cultures not only differ not only in the character of their organization, but also in their symbolic meaning - war/death versus fertility/life. This symbolic antagonism is referenced to the Indo-European variant of the myth about the Divine Twins, which
\end{abstract}


are closely related to the topic of charioting/horse riding and embody the following antitheses: the cults of war and fertility, the warrior's horse and the farmer's horse, producing and destructive functions of society.

Keywords: Southern Trans-Urals, Bronze Age, Sintashta culture, Petrovka culture, funerary rite, paired horse sacrifices

Citation. Kupriyanova E., 2021. Internal conflict of dual symbolism or the conflict in society: paired horse sacrifices from the necropolises of the Sintashta and Petrovka culture in the Southern Trans-Urals and Kazakhstan. Ufimskij arkheologicheskiy vestnik [The Ufa Archaeological Herald]. Vol.21, no. 2, pp. 274-297. (In Russ.). DOI: https://doi. org/10.31833/uav/2021.21.2.007

\section{Введение}

Одним из ярчайших феноменов в археологии бронзового века Урала и Казахстана являются памятники синташтинско-петровского культурнохронологического горизонта. Петровская археологическая культура была выделена в свое время выдающимся археологом Г.Б.Здановичем. Благодаря его же вкладу в археологию, научным сообществом во многом было осознано значение укрепленных поселений синташтинско-аркаимского типа как культурного и социального образования эпохи бронзы Центральной Евразии. Исследования последних лет, проводящиеся на поселениях и могильниках синташтинской и петровской культур, показывают, что до полного понимания процессов культурогенеза, формирования экономики и социума, происходивших в степях Южного Зауралья в бронзовом веке, еще далеко. Каждый раз эти памятники раскрываются исследователям с новой стороны в своей сложности и своеобразии.

Анализ погребального обряда, проделанный нами ранее на обширном материале (данные 47 могильников, включающих 356 курганов и грунтовые кладбища), выявляет в некрополях среднего-позднего бронзового века Южного Зауралья и Казахстана лишь две устойчивые модели обряда, обладающие характерным набором признаков: погребения с колесничной символикой и погребения в «позе объятия» [Куприянова, 2018]. Два сюжета (модели), ввиду своей необычной формы и устойчивых характеристик, явно воплощают некие мифологические представления или моделируют социальные отношения, где в основу положен концепт парности. В синташтинско-петровской культурной традиции погребения с такой символикой по набору инвентаря и позиции в некрополе носят ярко выраженный элитный характер. При этом в петровских памятниках черты двух моделей могут совмещаться и пересекаться (колесничная тематика встречается в могилах с погребениями в «позе объятия»), а в синташтинских проявляется сепаратно. В последующий период (алакульская культура) изменение количества и характера «мужской» и «женской» моделей в погребальном обряде культурных групп эпохи бронзы Южного Зауралья отражает постепенное снижение их мифо-ритуальной символики, а затем полное исчезновение (колесничная тема), либо использование для обозначения реального жизненного статуса индивидов (погребения в «позе объятия»).

Анализу погребений эпохи бронзы в «позе объятия» посвящено немало работ [Рафикова,
2014; Берсенева, 2015; Куприянова, 2018; и др.]. Предметом более детального рассмотрения в данной статье будет являться традиция парного жертвоприношения лошадей, являющаяся неотъемлемой частью так называемого «колесничного комплекса». Особое внимание будет уделено анализу отличий типологии, характера, внутренней символики парных жертвоприношений лошадей в синташтинской и петровской культурах, до этого рассматривавшихся в исследованиях в основном в совокупности.

\section{История вопроса}

Традиционно, изучая жертвоприношения лошадей в эпоху бронзы, авторы связывают их лишь с развитием колёсного транспорта, в частности, с изобретением в тот период колесницы, а погребения с лошадьми называют погребениями воиновколесничих и изучают в предполагаемом ключе [Новоженов, 1994; Пыслару, 2000; Черленок, 2001; и др.]. Такая точка зрения не лишена доли истины, но, на наш взгляд, символика данного феномена несколько шире.

Колесничество - яркий феномен культуры степных-лесостепных племён эпохи бронзы Центральной Евразии, который многие исследователи связывают с миграциями ранних индоевропейцев. $\mathrm{B}$ археологических памятниках его проявления разнообразны: находки остатков конской упряжи в могильниках и на поселениях, остатки колесниц в погребениях, жертвенные комплексы с лошадьми, наскальные изображения и изображения колесниц на предметах и пр. Среди культур эпохи бронзы Урало-Поволжья признаки колесничества в том или ином виде присутствуют в катакомбной культурно-исторической общности (КИО), бабинской культуре (культура многоваликовой керамики), абашевской КИО, памятниках потаповского культурного типа, синташтинской, петровской, алакульской, окуневской культурах, андроновской КИО, карасукской культуре [Чечушков, 2013. С. 18-20]. Однако самые яркие и массовые проявления данного феномена, по общему признанию, локализуются в Южном Зауралье и Казахстане в памятниках синташтинско-петровского круга.

Колесничный комплекс в изучаемом регионе, как явление сложное и неординарное, неоднократно подвергался рассмотрению в различных аспектах. Так, в диссертации И.В. Чечушкова [Чечушков, 2013] и ряде его статей, в том числе с соавторами [Чечушков, 2011; Чечушков, Епимахов, 2010; и др.], рассматривался колесничный комплекс, включающий остатки упряжи и колесниц как исторический 
феномен, а также проводилась реконструкция их использования в военном деле и обрядах. В нескольких работах [Черленок, 2000; 2001; Зданович Д., Куприянова, 2008; 2010; и др.] изучению и классификации подвергались жертвенники с лошадьми. Масса исследований касается изучения псалиев, их типологии, следов использования как в обрядах, так и в быту [Бочкарёв, Кузнецов, 2014; Усачук, 2013; Kupriyanova et al, 2017; Куприянова, Усачук, 2020; и др.].

Исследованию семантики и мифологической подоплеки колесничного феномена синташтинской культуры посвящен ряд статей С.В.Сотниковой [Сотникова, 2014a; 2014б; 2021]. В своих работах автор предлагает несколько выводов (отражение колесничества в погребальном обряде свидетельствует о проведении соревнований воинов-колесничих во время похорон, принесении в жертву коня, победившего в соревнованиях; о существовании различных вариантов жертвоприношения лошадей как результате инокультурных вмешательств, и пр.). Ряд критических замечаний не позволяет относиться всерьез к предложенным автором тезисам. В исследованиях, хоть и упоминаются свидетельства существования колесничества в различных культурах и в других памятниках синташтинского круга, но выводы делаются на основании единичных примеров Синташтинского большого грунтового могильника при полном игнорировании материалов других памятников. Более чем сомнительными являются методические процедуры исследования, где статистический, типологический и количественный анализ отсутствуют полностью, а в качестве аргументов приводятся данные поздних письменных источников (Илиада, Ригведа, хеттские тексты).

\section{Методика исследования}

В рамках данной статьи мы, ограничиваясь выбранным культурно-хронологическим горизонтом, рассматриваем лишь памятники синташтинско-петровского круга (исключая даже такие близкие явления, как покровские и потаповские памятники Поволжья), где наблюдается сочетание как наибольшего количества признаков колесничного комплекса в рамках отдельных погребальных объектов, так и наибольшее количество находок таких объектов, дающих базу для типологии и выделения характерных признаков.

Традиция парных жертвоприношений лошадей в территориальном и хронологическом планах совпадает с «ядром» традиций колесничества, но, при детальном рассмотрении в символическом плане оказывается несколько шире этого феномена. С одной стороны, существуют погребения, содержащие остатки или имитацию колесниц, с другой стороны (как будет показано ниже), далеко не все погребения, содержащие останки жертвенных лошадей, имеют следы колесниц, и не все погребения, имеющие следы колесниц, содержат жертвенники с лошадьми. В данном исследовании мы попытались впервые, используя максимальное количество доступных на сегодняшний день источ- ников, всесторонне подойти к рассмотрению темы парных жертвоприношений лошадей в различных проявлениях погребальной обрядности. Базой для анализа стали жертвоприношения лошадей - как сопровождавшие остатки колесниц, так и без них, а также погребения с признаками колесничного комплекса, но без сопровождавших их жертвенников.

В процессе рассмотрения была создана комплексная типология, включающая распространение различных типов жертвенников в рассматриваемых культурах, их связь с содержанием погребений, структурой погребальных комплексов, отражением мифологических сюжетов. Было рассмотрено 96 объектов из погребальных памятников, содержащих жертвоприношения лошадей (65 объектов с 11 памятников синташтинской культуры и 31 объект с 14 памятников петровско-алакульского круга) (Синташтинский большой грунтовый могильник (CM), могильники Каменный Амбар 5, Солнце II, Бестамак, Большекараганский (БК), Синташтинский комплекс грунтовых и курганных захоронений (CI), Синташтинский малый грунтовый могильник (CII), Синташтинский малый курган (CIII), Степное-1, Кривое Озеро, Танаберген II, Берлик, Графские развалины, Аксайман, Новоникольское, Семипалатное, Степное VII, Нуртай, Аяпберген, Ащису, Хрипуновский, Озерное-1, Майтан) [Генинг, Зданович, Генинг, 1992; Епимахов, 1996; 2005; Логвин, 2019; Виноградов, 2003; Боталов, Григорьев, Зданович Г., 1996; Зданович Д., 2002; Куприянова, 2016; Ткачёв В., 2007; Зданович Д., Куприянова, 2010; Ткачёв А., 2002; 2019; Кукушкин, 2006; 2007; Епимахов, Новиков, 2017; Куприянова, Зданович Д., 2015; Матвеев, 1998]. Краткие характеристики и параметры каждого комплекса приведены в приложениях 1-2 (прил. 1 - синташтинская культура; прил. 2 - петровская культура).

\section{Типология}

\section{захоронений «колесничных лошадей»}

Первая попытка по созданию типологии захоронений «колесничих лошадей» была предпринята в статьях Е.А. Черленка [2000; 2001]. Основываясь на доступных материалах синташтинско-петровского круга, покровских и потаповских памятников, автор создал базу для классификации подобных объектов. Предложено три типа:

- тип А: черепа и конечности двух лошадей, находящиеся в погребальной камере (синташтинская культура);

- тип Б1: костяки двух лошадей, расположенные на перекрытии погребальной камеры (синташтинская, петровская культуры, потаповский культурный тип);

- тип Б2: костяки двух лошадей, лежащие на краю ямы (петровская, покровская культура, потаповский культурный тип).

Указанные типы, как считает автор, возникали в хронологическом порядке их перечисления, хотя и сосуществовали какое-то время [Черленок, 2000. C. 348]. Ранее нами была предложена расширен- 


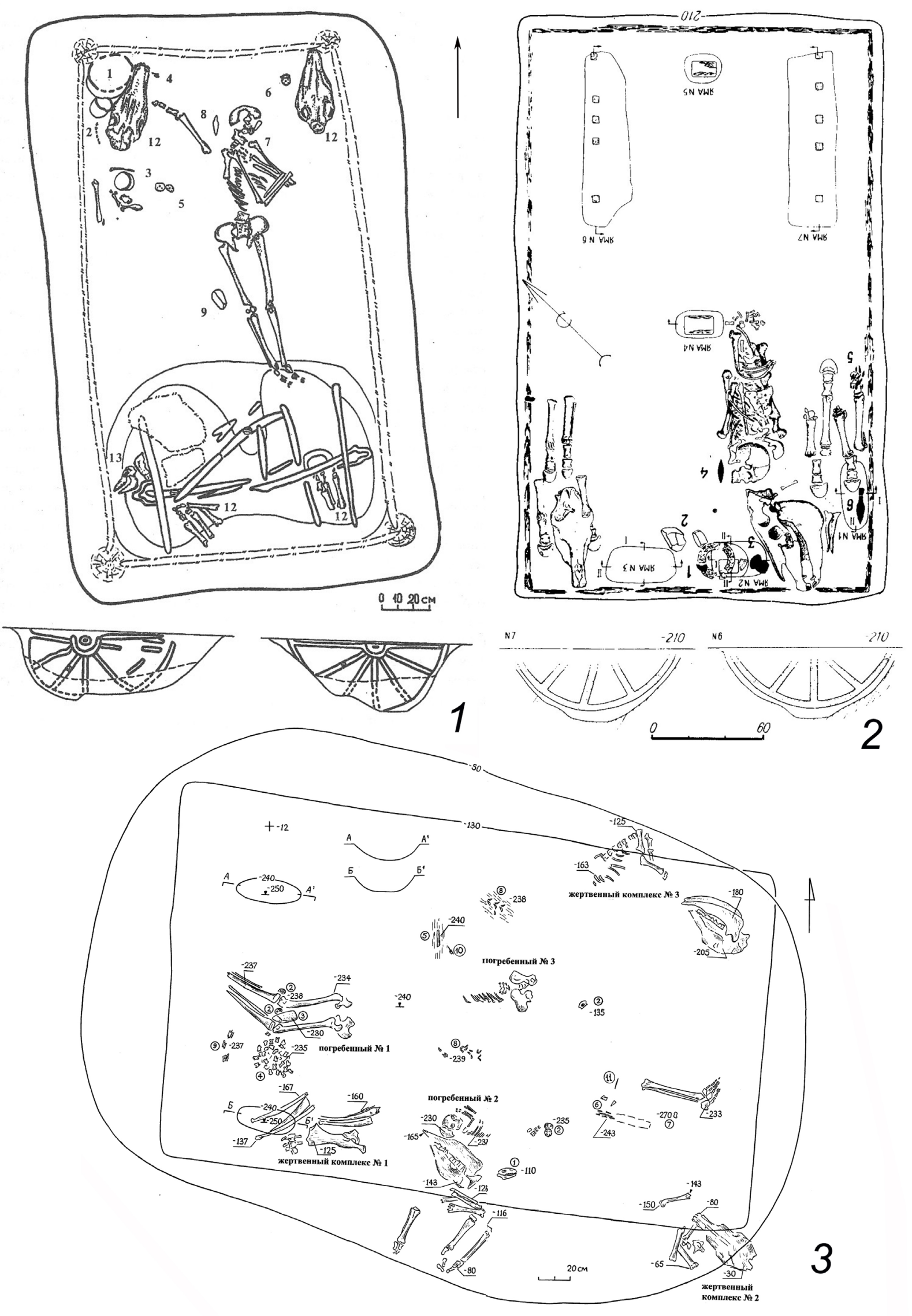

Рис. 1. Парные жертвоприношения лошадей, жертвенники типов A1 (1-2) и А2 (3): 1 - мог. Кривое Озеро (по: [Виноградов, 2003. Рис. 34]); 2 - Синташтинский большой грунтовый могильник (по: [Генинг, Зданович, Генинг, 1992. Рис. 111]); 3 - мог. Степное-1 (по: [Куприянова, 2016. Рис. 14])

Fig. 1. Paired horse sacrifices, sacrifices of types A1 (1-2) and A2 (3): 1 - Krivoe Ozero necropolis (after: [Vinogradov, 2003. Fig. 34]); 2 - Sintashta large necropolis (after: [Gening, Zdanovich, Gening, 1992. Fig. 111]); 3 - Stepnoye-1 necropolis (after: [Kupriyanova, 2016. Fig. 14]) 
ная схема данной классификации на основе более широкого материала [Зданович Д., Куприянова, $2008 ; 2010]$. В последнее время в научный оборот введено большое количество новых памятников, позволяющих скорректировать и расширить ранее предложенную типологию. Предлагаемая здесь типология выходит за рамки «колесничной» тематики, носит комплексный характер и учитывает несколько признаков: форма репрезентации жертвы (труп животного/набор частей трупа); положение жертвы относительно погребения, положение животных в жертвеннике, ориентация, наличие/ отсутствие и содержание колесничного комплекса (следы колесниц/псалии), культурная атрибуция.

При анализе материал группировался в две таблицы по культурному признаку: синташтинские погребения и комплексы петровско-алакульского круга. Единичные факты парных жертвоприношений лошадей в алакульских комплексах отмечены в памятниках, содержащих петровский и алакульский компоненты. Они отнесены к петровской традиции, так как четкое культурное разделение объектов в таких могильниках часто вызывает трудности, а алакульские памятники, не имеющие петровской составляющей, колесничных комплексов не содержат.

Предлагаемая здесь расширенная типология выглядит следующим образом.

Тип $\mathbf{A}$ - жертвенники из голов и ног лошадей («частичное животное»), делится на три подтипа.
A1 (рис. 1, 1-2). Пара жертвенных особей располагается на дне могилы. Тип А1 отмечен исключительно в синташтинских комплексах (10 случаев из $65-15,4 \%)$. В большинстве случаев (7 из 10) могила с жертвенником имитирует колесницу, головы лошадей располагаются параллельно друг другу, перед следами колес («по обе стороны дышла»). Тип А1 подразумевает обособленное от остальных жертв положение лошадей.

$\mathbf{A 2}$ (рис. 1, 3). Жертвенники располагаются на перекрытии. Тип А2 в подавляющем большинстве принадлежит синташтинским комплексам (21 случай из $65-32,3 \%)$, и лишь в одном случае $(3,2 \%)$ отмечен в петровском памятнике. В основном (12 случаев из 21) в могиле отсутствуют следы имитации колесниц, расположение жертвенников в пространстве более свободное. Парные жертвоприношения лошадей по типу А2 чаще всего входят в состав более крупных жертвенных комплексов с останками крупного и мелкого рогатого скота, занимая при этом высшую ступень в иерархии жертв [Zdanovich, Gayduchenko, 2002. P. 202-231].

$\mathbf{A 3}$ (рис. 2). Останки двух лошадей (головы и дистальные отделы конечностей) размещаются за пределами могильной ямы, в отдельной яме или на подкурганной площадке. Тип встречается достаточно редко как в синташтинских, так и в петровских памятниках. Всегда сопровождает комплексы, где присутствуют другие типы жертвенников с лошадьми, относящиеся к конкретным погребе-

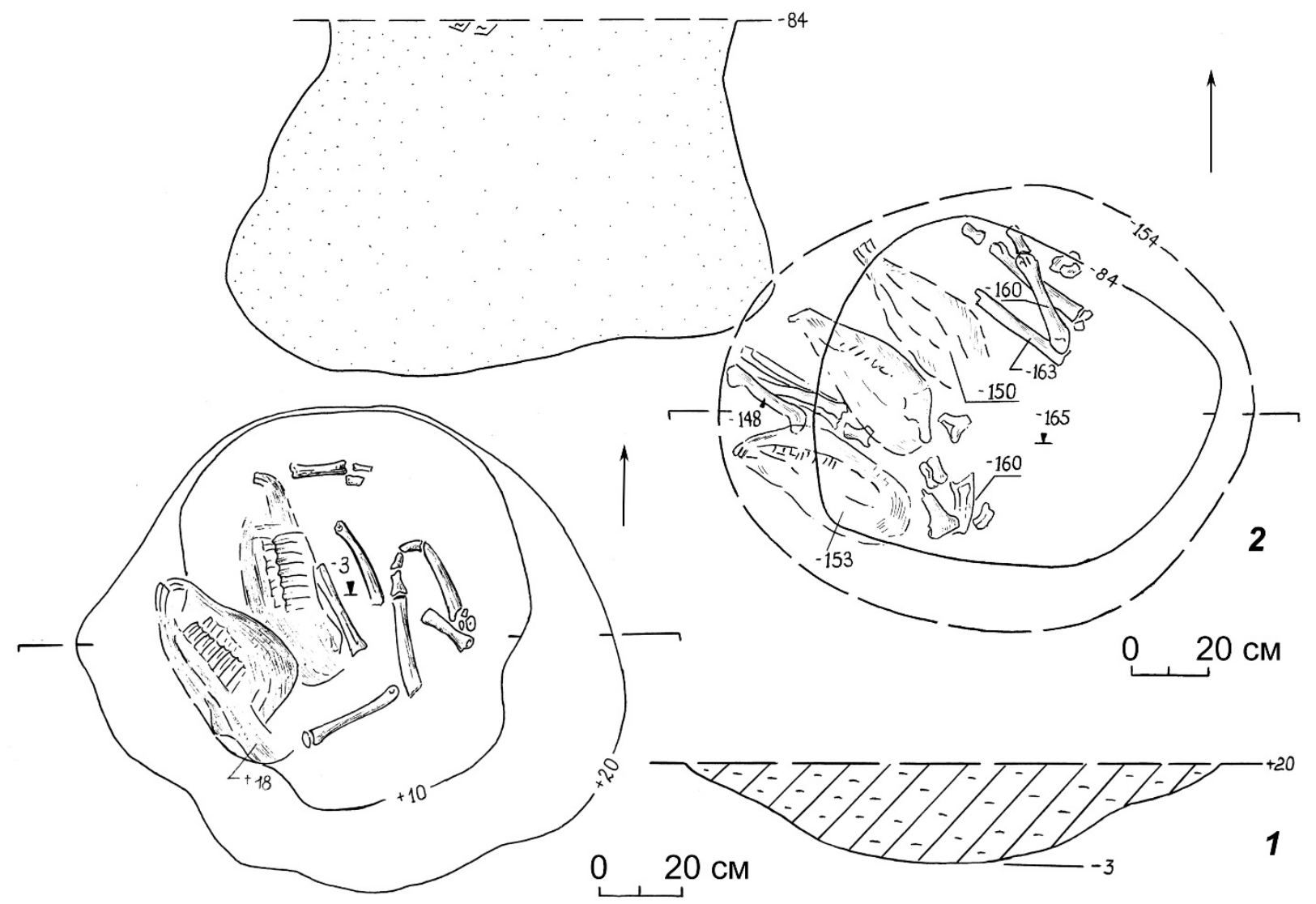

Рис. 2. Парные жертвоприношения лошадей, жертвенники типа А3: 1 - мог. Степное-1, курган 5; 2 - мог. Степное-1, курган 1 (по: [Куприянова, 2016. Рис. 35, 26])

Fig. 2. Paired horse sacrifices, sacrifices of type A3: 1 - Stepnoye-1 necropolis, barrow 5; 2 - Stepnoye-1 necropolis, barrow 1 (after: [Kupriyanova, 2016. Fig. 35, 26]) 

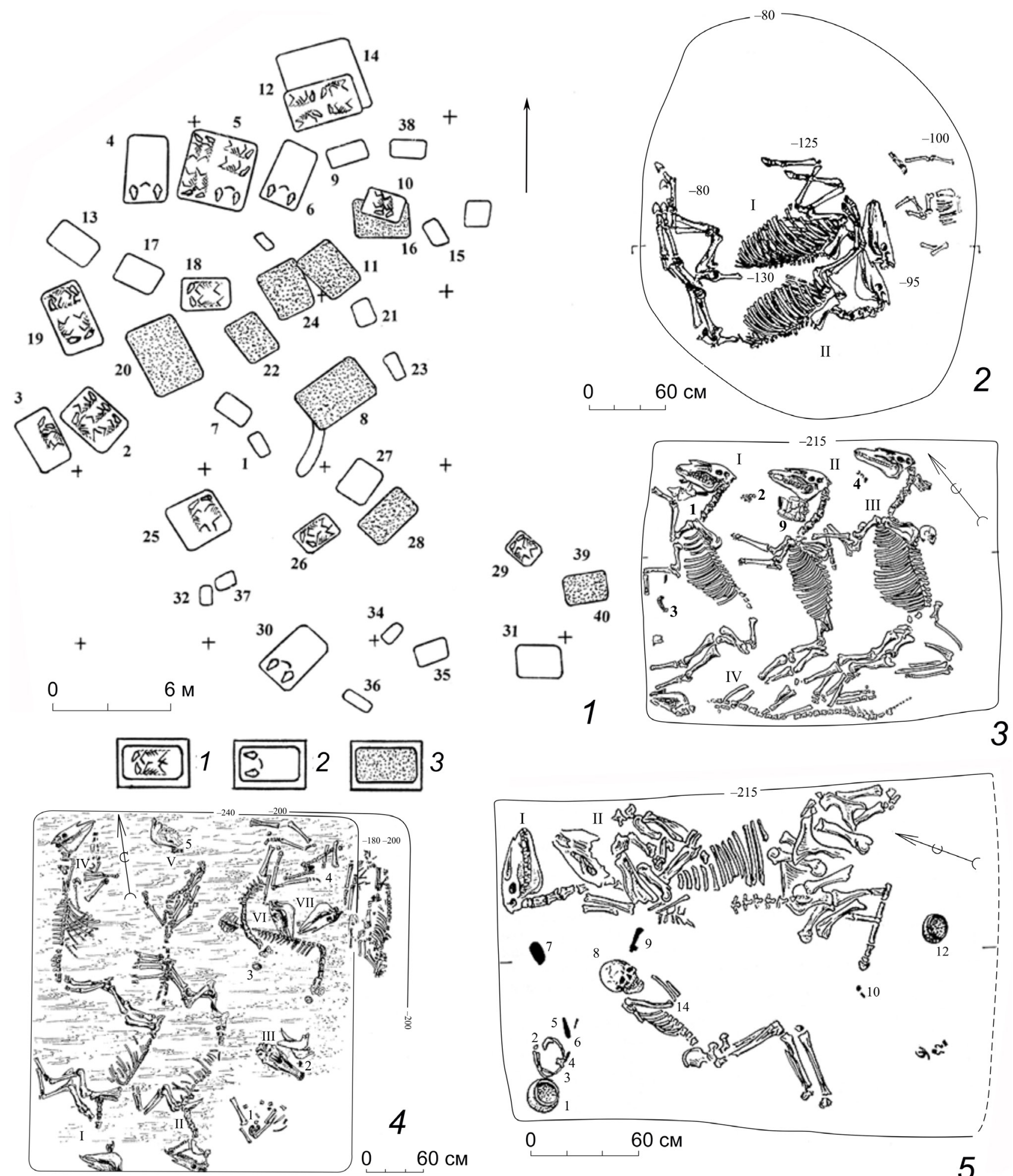

Рис.3. 1 - распределение жертвенных комплексов в погребениях Синташтинского большого грунтового могильника (1 - целые костяки лошадей (жертвенники типа Б1); 2 - жертвенные комплексы «голова + ноги» (жертвенники типа А); 3 - разрушенные жертвенные комплексы с останками лошадей либо единичные кости лошадей); $2-5$ - жертвенные комплексы типа Б1 (Синташтинский грунтовый могильник, погребения 2, 3, 5, 10) $(2-5$ - по: [Генинг, Зданович, Генинг, 1992. Рис. 65; 45; $53 ; 48])$

Fig. 3. 1 - distribution of the sacrificial assemblages in the burials of the Sintashta large necropolis $(1-$ horse carcasses (sacrifices of type B1); 2 - sacrifices with "heads + legs" (sacrifices of type A); 3 - destroyed sacrificial assemblages with horse remains or single bones of horses); 2-5 - sacrificial assemblages of type B1 (Sintashta large necropolis, burials 2, 3, 5, 10) $(2-5$ - after: [Gening, Zdanovich, Gening, 1992. Fig. 65; 45; 53; 48])

ниям. В виду частого повреждения верхних слоёв погребальных памятников, можно предположить, что часть жертвенников этого типа не сохраняется. По имеющимся материалам нами зафиксированы два случая (3\%) в синташтинских и один случай $(3,2 \%)$ в петровских комплексах.
Тип Б - жертвенники из целых туш лошадей, делится на три подтипа.

Б1 (рис. 3) - костяки двух лошадей располагаются на перекрытии погребальной камеры. Тип зафиксирован преимущественно в синташтинских комплексах (20 случаев из 65 - 30,8\%), в 
единственном числе (3,2\%) отмечен в петровских комплексах. В типе не выделяется четких подвариаций, но он имеет свои характерные черты. Отмечена четность количества костяков лошадей на перекрытиях. ${ }^{1}$ Костяки лошадей расположены в пространстве могилы парами. Например, в могильнике БестамакI их число почти всегда равно двум, в могильнике СМ данное число достигает шести, но по взаиморасположению можно легко выделить пары (см. рис. 3, 1). По положению костяков друг относительно друга выделяется четыре основных варианта: на одном боку, ногами друг к другу, ногами в противоположные стороны, валетом ${ }^{2}$ (такие же варианты расположения характерны для типа Б2 (см. ниже), а также для парных изображений животных в различных культурных традициях). В могилах в подавляющем большинстве случаев отсутствуют следы колесниц.

Б2 - костяки двух лошадей лежат на краю ямы. Тип отмечен исключительно в петровско-алакульских комплексах (15 случаев из 31 - 58,1\%). Здесь можно различить четыре подварианта обряда:

1. Костяки лошадей расположены вдоль длинных стен ямы, на её краях, ногами друг к другу - 4 случая (рис. 4, 1-2);

2. Костяки лошадей расположены вдоль длинных стен ямы, на её краях, ногами в противоположные стороны - 3 случая (рис. 4, 3-4);

3. Костяки лошадей расположены рядом с одной стороны ямы, ногами друг к другу (ноги сплетены) - 7 случаев (рис. 5);
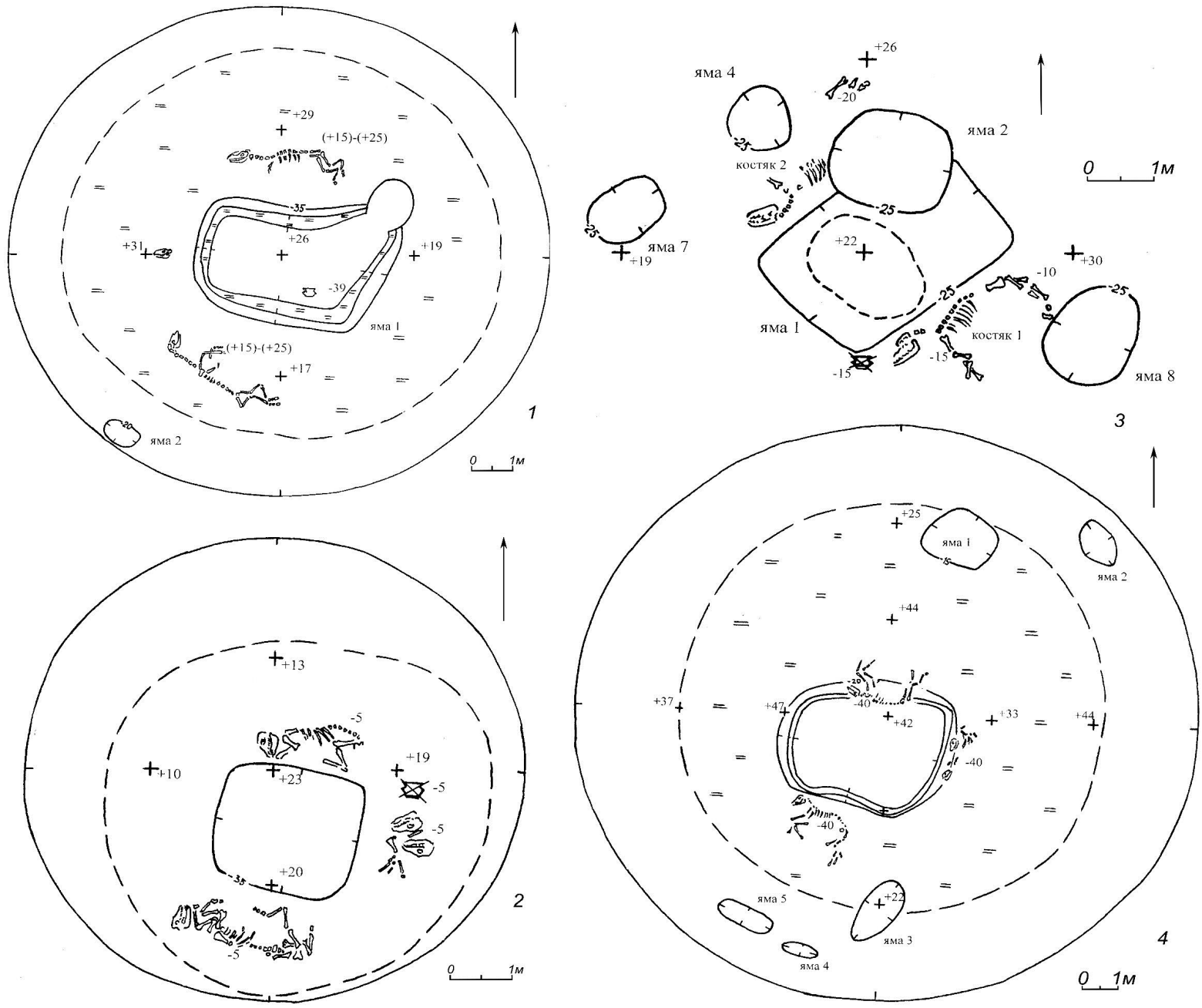

Рис. 4. Парные жертвоприношения лошадей, жертвенники типа Б2-1 (1-2) и Б2-2 (3-4): 1 - мог. Берлик II, к. 1; 2 - мог. Графские Развалины, к. 15 (по: [Зданович Д., Куприянова, 2010. Рис. 3]); 3 - мог. Аксайман, раскоп 4; 4 - мог. Берлик II, к. 2 (по: [Зданович Д., Куприянова, 2010. Рис. 4])

Fig. 4. Paired horse sacrifices, sacrifices of type B2-1 (1-2) and B2-2 (3-4): 1 - Berlik II necropolis, kurgan 1; 2 - Grafskiye razvaliny necropolis, barrow 15 (after: [Zdanovich D., Kupriyanova, 2010. Fig. 3]); 3 -Aksayman necropolis, excavation 4; 4 - Berlik II necropolis, barrow 2 (after: [Zdanovich D., Kupriyanova, 2010. Fig. 4])

${ }^{1}$ Два замеченных исключения из этого правила должны быть оговорены отдельно. В случае с погребением 18 СМ авторами публикации явно был не замечен второй костяк лошади, располагающийся параллельно первому, сильно разрушенный вследствие ограбления ямы. На чертеже видны кости передних конечностей, позвонки поясничного и грудного отделов второй лошади, располагавшейся, видимо, на левом боку, ногами к первой особи. В погребении 5 могильника Бестамак I число костяков равно трем. Два из них (расположенные вдоль северной и южной стен, головой на запад) образуют пару. Пару третьей лошади, по нашему мнению, составляет лошадь из жертвенного комплекса, приуроченного к данному погребению.

2 Два нетипичных случая на могильнике Бестамак I (погр. 1,45$)$, где лошади лежат на брюхе, не портят картины, т.к. в обоих случаях лошади расположены не на перекрытии, а в могильной яме. 
4. Костяки лошадей расположены рядом с одной стороны ямы, ногами в противоположные стороны - 4 случая (рис. 6).

Соотношение подтипов в жертвенниках типа Б2 в процентном соотношении неравномерно (рис.7) - чаще отмечены жертвенные комплексы подтипа Б2-3. Однако численный разрыв не так велик, и его можно отнести за счет недостатка материала. Для всех подвариантов типа Б2 характерны следующие общие черты:

1. Ориентировка лошадей головами в западный сектор (для типов А и Б1 можно говорить лишь о тенденции к преобладанию западной ориентировки, но многое зависит от ориентации могильной ямы (см. прил. 1-2), в то время как в типе Б2 констатируется ее стопроцентный характер);

2. Расположение костяков на специально сделанных вокруг центральных ям глиняных площадках или выкиде из погребений (на чертежах их контуры показаны пунктиром (рис. 4-6). Характерный ритуальный элемент, сопровождающий жертвенники типа Б2, - следы огня над ямой или рядом на площадке.

Б3 (рис. 8) - захоронение трупов лошадей в отдельных ямах на подкурганных площадках. Тип редок и отмечен исключительно в петровских па- мятниках - два случая (6,5\%). В культурах Центральной Евразии эпохи бронзы других регионов такие жертвенники также встречаются (Утевский могильник, Баранниково, Уваровский II) [Васильев, 2015; Михайлова, Кузьмина, 1999]. Парные захоронения лошадей в отдельных ямах хорошо известны в греко-микенском мире: Марафонский толос [Vanderpool, 1959. Р.279-283], комплекс в Саламисе на Кипре [Vermeule, 1979. Р.60], парные захоронения лошадей субмикенского времени на Крите [Day, 1984. P.25]. Подобные ритуальные захоронения лошадей представлены и в скифских курганах [см. напр.: Тереножкин, Мозолевский, 1988. C. 49, 52-62].

Типы А3 и Б3 не связаны с собственно погребениями и представляют собой отдельные жертвенные ямы.

Таблицы с материалами при проведении аналитики позволяют сделать ряд выводов о культурном распространении, эволюции и семантике выделенных типов. Выявлена совершенно четкая система культурной принадлежности различных вариантов жертвенников. Как видно из таблицы 1, разные варианты в синташтинских ипетровских комплексах практически не пересекаются.

Распределение типов жертвенных комплексов с парными лошадьми в синташтинских и петровских некрополях Table 1

Distribution of the burials with paired horse sacrifices in the necropolises of the Sintashta and Petrovka cultures

\begin{tabular}{|c|c|c|c|c|c|c|c|c|c|c|c|}
\hline \multicolumn{6}{|c|}{$\begin{array}{c}\text { Синташтинская культура - } \\
65 \text { объектов }(100 \text { \%) } \\
\text { Из них неопределимых } 12(18,5 \%)\end{array}$} & \multicolumn{6}{|c|}{$\begin{array}{c}\text { Петровская культура - } \\
31 \text { объект (100\%) } \\
\text { Из них неопределимых } 8(25,8 \text { \%) }\end{array}$} \\
\hline \multicolumn{3}{|c|}{ Тип А } & \multicolumn{3}{|c|}{ Тип Б } & \multicolumn{3}{|c|}{ Тип А } & \multicolumn{3}{|c|}{ Тип Б } \\
\hline $\begin{array}{c}\text { Подтип } \\
1 \\
\end{array}$ & $\begin{array}{c}\text { Подтип } \\
2 \\
\end{array}$ & $\begin{array}{c}\text { Подтип } \\
3 \\
\end{array}$ & $\begin{array}{c}\text { Подтип } \\
1 \\
\end{array}$ & $\begin{array}{c}\text { Подтип } \\
2 \\
\end{array}$ & $\begin{array}{c}\text { Подтип } \\
3 \\
\end{array}$ & $\begin{array}{c}\text { Подтип } \\
1 \\
\end{array}$ & $\begin{array}{c}\text { Подтип } \\
2 \\
\end{array}$ & $\begin{array}{c}\text { Подтип } \\
3 \\
\end{array}$ & $\begin{array}{c}\text { Подтип } \\
1 \\
\end{array}$ & $\begin{array}{c}\text { Подтип } \\
2 \\
\end{array}$ & $\begin{array}{c}\text { Подтип } \\
3 \\
\end{array}$ \\
\hline $\begin{array}{c}10 \\
(15,4 \%)\end{array}$ & $\begin{array}{c}21 \\
(32,3 \%)\end{array}$ & $\begin{array}{c}2 \\
(3 \%)\end{array}$ & $\begin{array}{c}20 \\
(30,8 \%)\end{array}$ & - & - & - & $\begin{array}{c}1 \\
(3,2 \%)\end{array}$ & $\begin{array}{c}1 \\
(3,2 \%)\end{array}$ & $\begin{array}{c}1 \\
(3,2 \%)\end{array}$ & $\begin{array}{c}18 \\
(58,1 \%)\end{array}$ & $\begin{array}{c}2 \\
(6,5 \%)\end{array}$ \\
\hline
\end{tabular}

Таким образом, характерными для синташтинской культуры типами являются А1, А2, Б1; для петровских памятников доминирует тип Б2 (рис.9). Типы А3 и Б3 не являются распространёнными, а скорее вторичными. Наличие нехарактерных для культуры типов жертвенников в комплексах можно признать единичными случаями, не влияющими на общую схему.

Парность является неотъемлемой характеристикой для жертвенников с лошадьми: в петровских комплексах она отмечена в $100 \%$ случаев, в синташтинских нечётное количество особей зафиксировано в 13 случаях (20\%). При этом большинство из них явно объясняется плохой сохранностью комплексов (петровские жертвенники менее страдают при ограблении ям).

Также можно отметить, что в некоторых случаях, включённых в таблицу, парность животных носит символический характер - только моделируется или обозначается:

- в погребении 12 кургана 25 Большекараганского могильника одна из двух особей лошади была обозначена астрагалом и пяточной костью;

- на дне ямы 85 могильника Степное VII на- ходился скелет жеребца; в головах был расчищен фрагмент лопатки другой лошади (рис. 10);

- в ограде 15 могильника Майтан одна из лошадей представлена целой тушей, вторая лишь ногами; и пр.

Приведенные примеры свидетельствуют о той важной роли, которую играла категория парности в жертвоприношениях лошадей в синташтинских и петровских комплексах.

Что касается традиционного стремления связывать жертвенники с лошадьми с колесничным комплексом - анализ материала показывает следующее:

-в синташтинских комплексах в 8 случаях (12,3\%) жертвенники с лошадьми сопряжены с остатками колесниц; в 12 случаях (18,5\%) - с находками псалиев; в 8 случаях (12,3\%) - с находками псалиев и остатками колесниц;

-в петровских комплексах остатками колесниц сопровождался один жертвенник $(3,2 \%)$, находками псалиев - 7 (22,6\%), находками псалиев и остатками колесниц - 5 жертвенников $(16,1 \%)$.

В целом, в синташтинской культуре признаки колесничного комплекса сопровождают 43,1 \% 


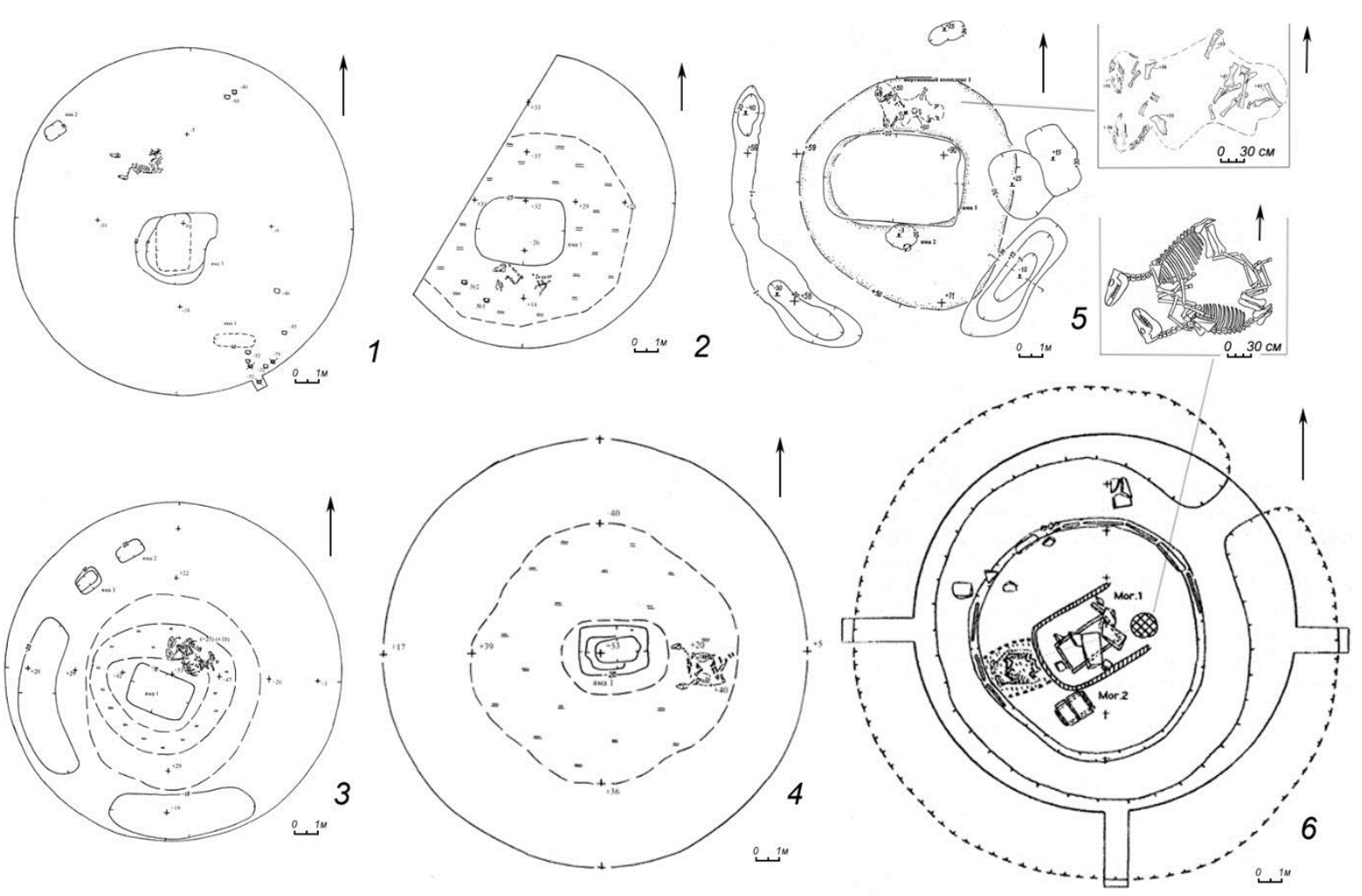

Рис. 5. Парные жертвоприношения лошадей, жертвенники типа Б2-3: 1 - мог. Семипалатное, к.2; 2 - мог. Берлик II, к. 10; 3 - мог. Графские Развалины, к. 14; 4 - мог. Новоникольское, к. 1 (1-4 - по: [Зданович Д., Куприянова, 2010. Рис. 5]); 5 - мог. Степное-1, к. 5 (по: [Куприянова, 2016. Рис. 52]); 6 - мог. Нуртай, к. 2 (по: [Ткачёв А., 2002. Рис. 53])

Fig. 5. Paired horse sacrifices, sacrifices of type B2-3: 1 - Semipalatnoye necropolis, barrow 2; 2 - Berlik II necropolis, barrow 10; 3 - Grafskiye razvaliny necropolis, barrow 14; 4 - Novonikolskoe necropolis, barrow 1 (1-4 - after: [Zdanovich D., Kupriyanova, 2010. Fig. 5]); 5 - Stepnoye-1 necropolis, barrow 5 (after: [Kupriyanova, 2016. Fig. 52]); 6 - Nurtai necropolis, barrow 2 (after: [TkachevA., 2002. Fig. 53])

жертвоприношений лошадей, в петровской $41,9 \%$, т.е. в обеих культурах их чуть меньше половины.

Отдельно стоит рассмотреть характер погребений, сопровождаемых жертвенниками с лошадьми. По нашим подсчетам, жертвоприношения лошадей сопровождают около $30 \%$ синташтинских погребений и около $13 \%$ погребений петровскоалакульской группы. При этом в синташтинских комплексах скорее правилом, чем исключением, является наличие таких жертвенников в нескольких (часто коллективных) погребениях одного кургана, разных типов жертвенников в погребении. В петровских комплексах лошади сопровождают обычно одно центральное индивидуальное погребение. В синташтинской группе (при меньшем количестве памятников) зафиксировано большее количество погребений с жертвенными лошадьми (11 памятников - 65 случаев), а в петровской группе - при большем количестве могильников - меньшее количество таких погребений (13 памятников - 31 случай).

Анализ половозрастного состава умерших, найденных в погребениях с остатками колесниц показывает, что там, где проводились антропологические определения, это либо индивидуальные мужские, либо коллективные погребения, из чего некоторые исследователи делают вывод о том, что «встречаемость колесниц в коллективных усыпальницах не позволяет однозначно утверждать, что она являлась маркером социального статуса конкретного погребенного» [Чечушков, 2013. C. 16].

На наш взгляд, все приведённые ранее факты свидетельствуют о том, что в синташтинской культуре практика жертвоприношения лошадей в погребальном обряде и символика, которую они воплощали (в том числе колесничная), являлись принадлежностью некоего коллектива, социальной группы. Об этом свидетельствует и характер жертвенников («частичные» животные), поскольку считается, что при такой схеме оставшаяся часть туши предназначается для ритуальной поминальной трапезы большого коллектива. В петровских комплексах они приобретают совершенно конкретный, индивидуальный элитарный статус, уменьшаясь количественно и сопровождая преимущественно центральные погребения индивидов мужского пола. В жертву приносятся целые туши, не предназначенные для употребления в пищу в поминальных трапезах. Возможно, это является свидетельством социальных трансформаций - перехода от власти элитного сословия к подобию вождества. В памятниках с доминирующим алакульским субстратом подобные комплексы исчезают.

Дальнейшее развитие традиции жертвоприношений лошадей в территориальном и хронологическом плане представляется следующим образом. Центральным «ядром» традиции, безусловно, является Южное Зауралье, прилегающие районы 

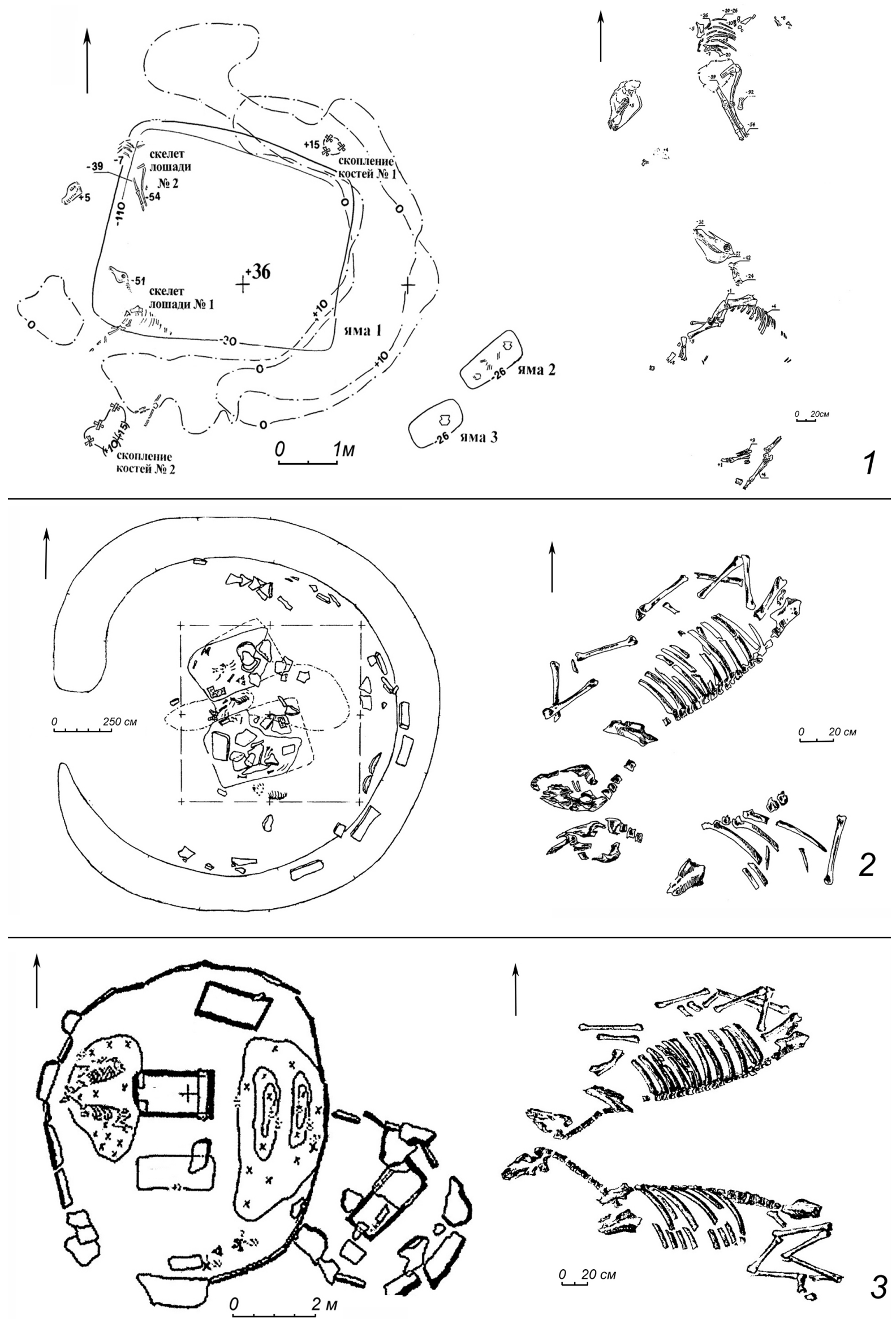

Рис. 6. Парные жертвоприношения лошадей, жертвенники типа Б2-4: 1 - мог. Степное-1, к. 8 (по: [Куприянова, 2016. Рис. 55]); 2 - мог. Ащису, к. 1 (по: [Кукушкин, 2007. Рис. 2]); 3 - мог. Аяпберген, к. 7 (по: [Кукушкин, 2006. Рис. 2])

Fig. 6. Paired horse sacrifices, sacrifices of type B2-4: 1 - Stepnoye-1 necropolis, barrow 8 (after: [Kupriyanova, 2016. Fig. 55]); 2 - Ashchisu necropolis, barrow 1 (after: [Kukushkin, 2007. Fig. 2]); 3 - Ayapbergen necropolis, barrow 7 (after: [Kukushkin, 2006. Fig. 2]) 


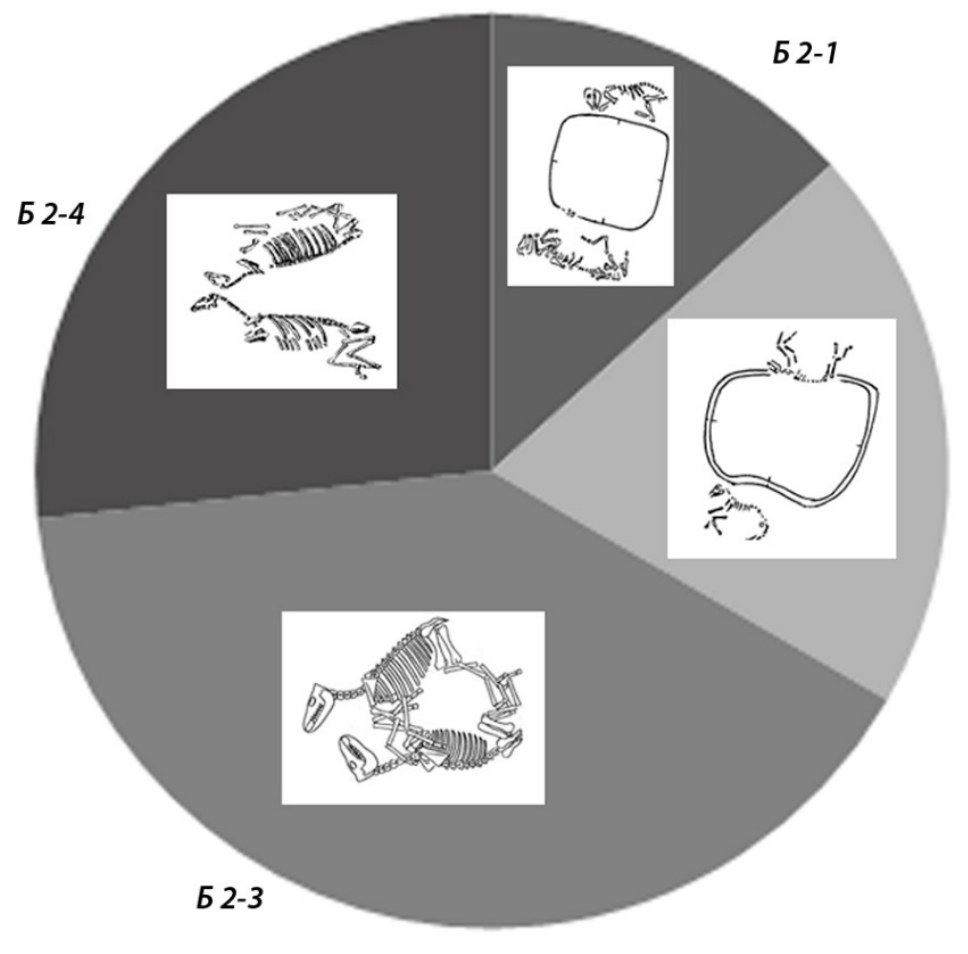

Б 2-2

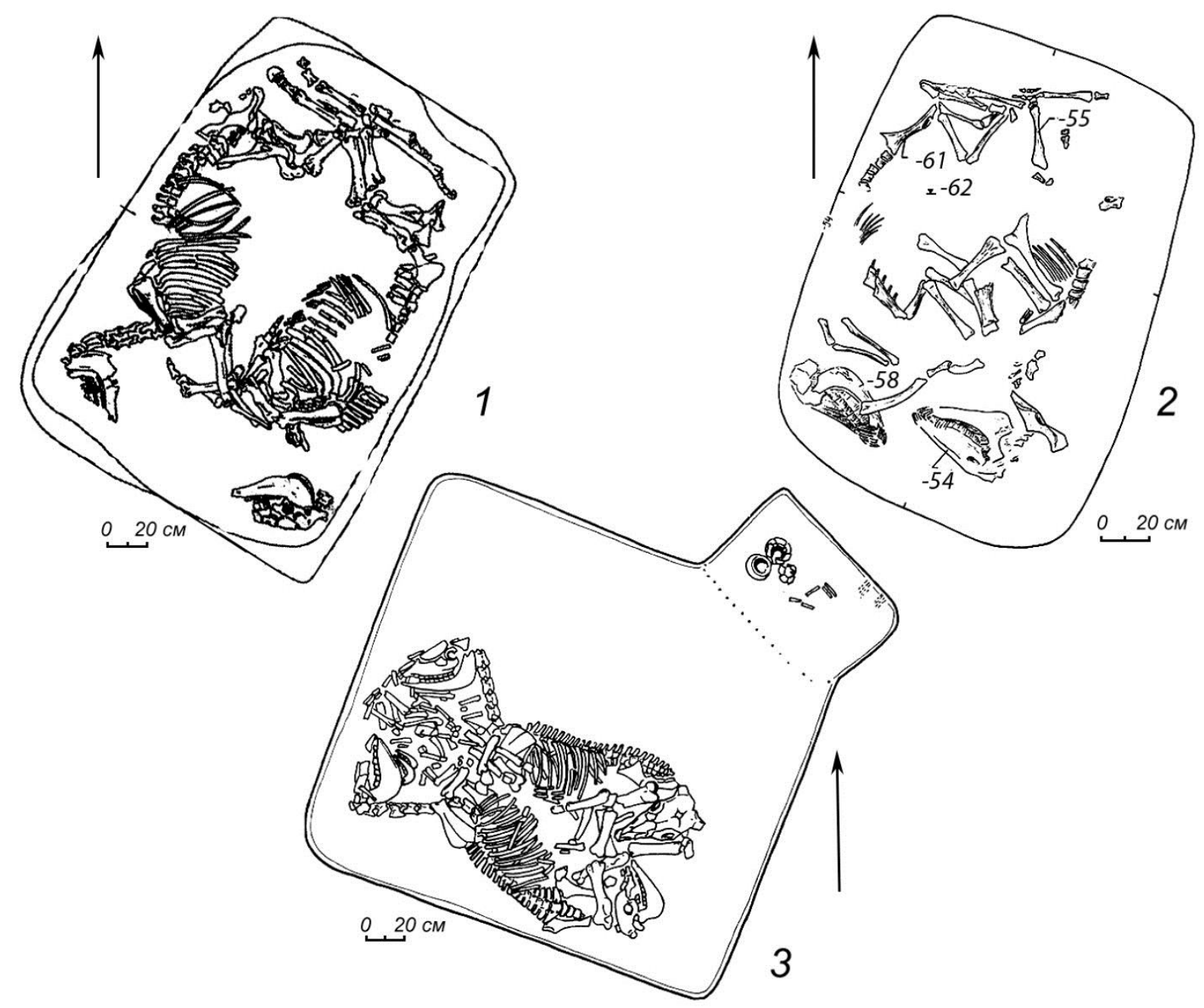

Рис. 8. Парные жертвоприношения лошадей, жертвенники типа Б3: 1 - мог. Уваровка II, к. 11, п.3 (по: [Михайлова, Кузьмина, 1999. Рис. 3]); 2 - мог. Степное VII, я. 70 (по: [Куприянова, Зданович Д., 2015. Рис. 111]); 3 - мог. Хрипуновский, я. 16 (по: [Матвеев, 1998. Рис. 56])

Fig. 8. Paired horse sacrifices, sacrifices of type B3: 1 - Uvarovka II necropolis, barrow 11 (after: [Mikhailova, Kuzmina, 1999. Fig. 3]); 2 - Stepnoye VII necropolis, pit 70 (after: [Kupriyanova, Zdanovich D., 2015. Fig. 111]; 3 - Khripunovsky necropolis, pit 16 (after: [Matveev, 1998. Fig. 56]) 


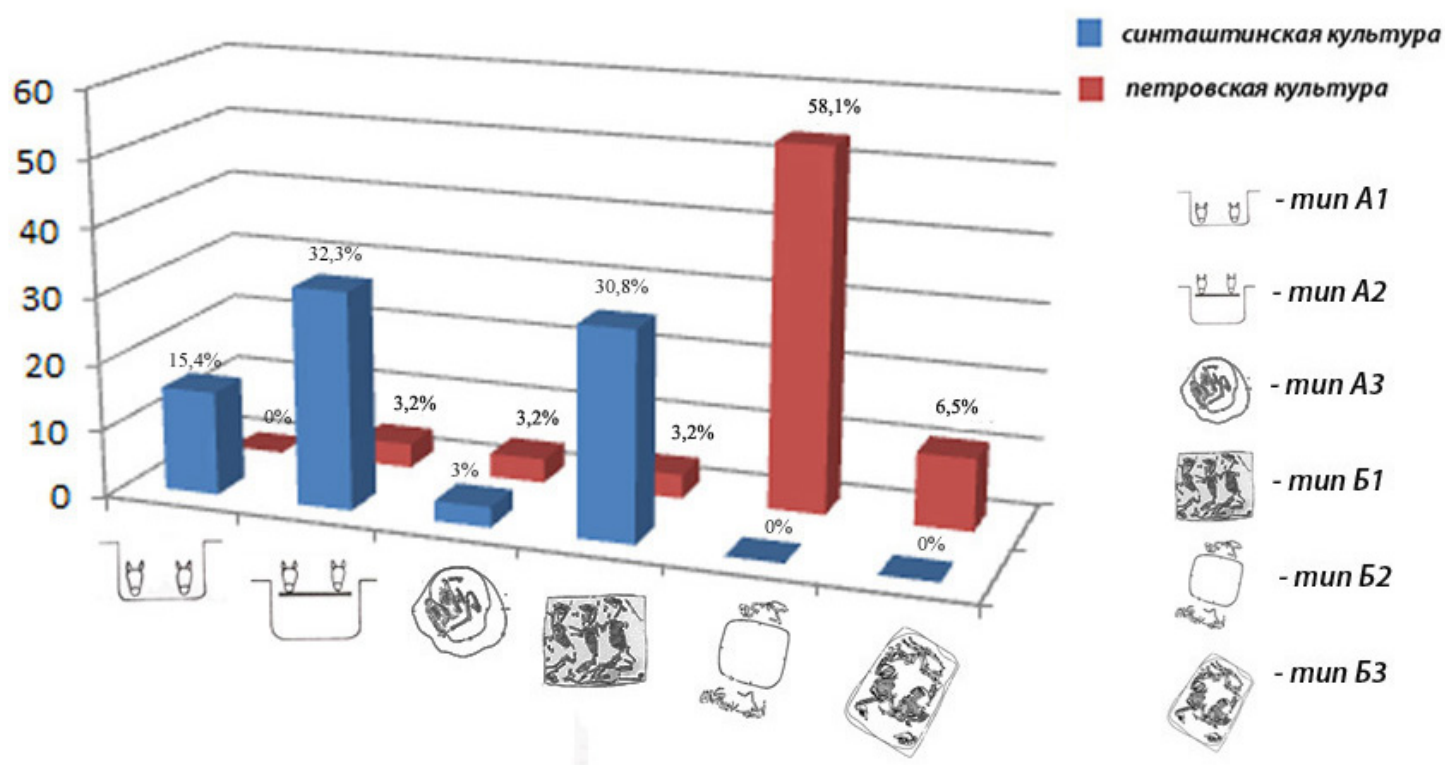

Рис. 9. Распределение типов жертвенников с лошадьми в памятниках синташтинской и петровской культур Fig. 9. Distribution of the types of horses sacrifices in the sites of the Sintashta and Petrovka cultures

Северного и Центрального Казахстана, где на рубеже III-IIтыс. дон.э. формируются памятники синташтинско-петровского круга. За пределами очерченной зоны традиция парных жертвоприно-

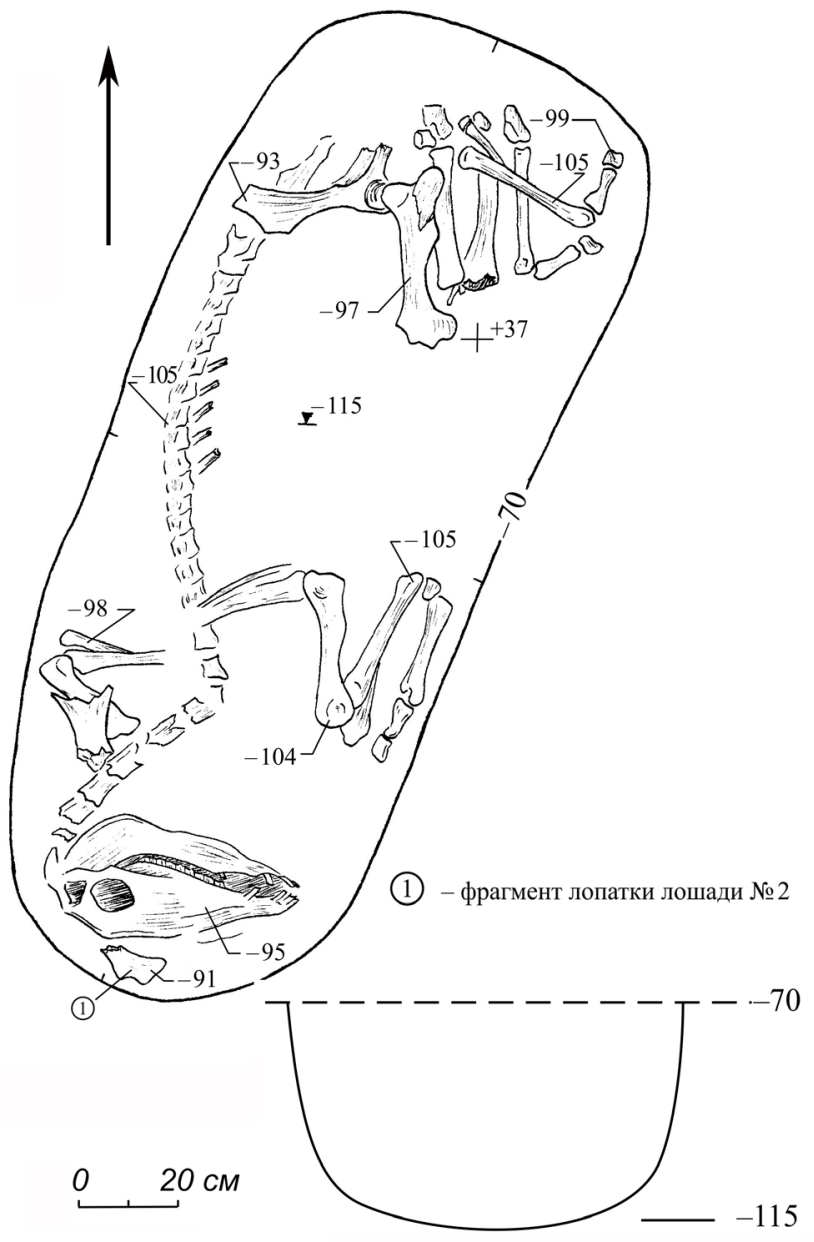

Рис. 10. Имитация парного жертвоприношения - целый костяк лошади + лопатка другой особи, мог. Степное VII, я. 85 (по: [Куприянова, Зданович Д., 2015. Рис. 124])

Fig. 10. Imitation of a paired sacrifice - a horse carcass + the shoulder blade of another horse, Stepnoye VII necropolis, pit 85 (after: [Kupriyanova, Zdanovich D., 2015. Fig. 124]) шений лошади угасает и вырождается, так же, как в поздний период подобное отмечается и на исследуемой территории [Епимахов, 2004. С. 105-111]. Угасание данной традиции наблюдается в западной части степей вплоть до бассейна Дона, а на востоке - в лесостепном Притоболье. Для Среднего Поволжья в целом, судя по опубликованным данным, характерны жертвенники типа Б2 и их имитации. Их облик весьма различен и не имеет общих черт, за исключением основного принципа - положения жертвенных лошадей за пределами могильных ям. Немного подобных комплексов и к северо-востоку от урало-казахстанских степей. Жертвенник типа Б1 раскопан в кургане 13 Алакульского могильника [Сальников, 1952. С. 56]. Не исключено, что жертвенник с останками двух лошадей был на могильнике Раскатиха в Притоболье [Потёмкина, 1985. С. 205, 285]. Крайней западной периферией традиции можно считать парные захоронения лошадей микенского и субмикенского времени в Марафоне, Дендре, на островах Эгейского и Средиземного морей [Makkay, 1996. Р. 777-784]. Здесь же (по крайней мере, в материковой Греции) выявлены и свидетельства использования местным населением колесничной упряжи степного типа.

Развитие тенденции во времени и пространстве сопровождается изменениями обряда. Жертвенники так называемого типа А (голова + ноги жертвенного животного) являются самой ранней, универсальной и повсеместной формой жертвоприношения, воплощая известную формулу "pars pro toto". В эпоху поздней бронзы изучаемого peгиона такой тип продолжает существовать и далее (в алакульской культуре подобные жертвенники характерны в основном для крупного и мелкого рогатого скота).

Угасание и размывание традиции в направлении от центра к дальней периферии, по-видимому, можно перенести и в сферу семантики культа. 
Таким образом, интерпретация символики жертвенников с лошадьми возможна, на наш взгляд, только для памятников синташтинско-петровского культурного горизонта урало-казахстанских степей, где имеется устойчивая традиция. Здесь выделяются типы и подтипы. На сопредельных территориях, на памятниках других культур (срубной, абашевской, потаповского типа и пр.) такая традиция представляется менее устойчивой.

\section{Семантика ритуалов}

\section{парных жертвоприношений лошадей}

Семантика ритуалов жертвоприношения парных лошадей, развившихся и достигших кульминации расцвета в синатштинской и петровской культурах, вполне очевидно связана с индоевропейской близнечной мифологией [Иванов, Топоров, 1991. С. 529]. Однако анализ материала позволяет предположить, что изначально имелись две тенденции в сооружении подобных жертвенников.

Представляется, что часть описанных жертвенников (около половины из них) связана с мифологическим сюжетом о близнецах-колесничих, о чем свидетельствует наличие следов колесниц в могилах, расположение жертвенников относительно них, подобно лошадям в упряжи, а также присутствие остатков конской упряжи, оружия дистанционного боя (всего, что входит в колесничный комплекс). Вторая половина, в которой отсутствуют признаки колесничного комплекса, связана с таким аспектом близнечного мифа, как символика плодородия.
Не исключено, что в синташтинских комплекcax часть погребений моделирует оба аспекта, поскольку здесь часто совмещаются колесничная тема и погребения в «позе объятия», в отличие от петровских, где представлены преимущественно одиночные мужские погребения. Определение пола лошадей в погребениях 12 и 24 кургана 25 Большекараганского могильника показало, что в одном погребении находятся разнополые особи. Bсе пары в жертвенниках могильников Степное 1 и Степное VII также имели разный пол. ${ }^{3}$ Пол лошадей на большинстве памятников, к сожалению, не определялся, но на могильнике СМ (погребение $10)$ положение лошадей явно напоминает позу совокупления животных (рис. 3, 2). Положение лошадей в третьем подварианте жертвенников типа Б2 и жертвенниках Б3 напоминает захоронения «в позе объятия», которые большинство авторов связывают с ритуалами плодородия. Ноги лошадей переплетены так же, как и конечности мужчины и женщины в подобных погребениях.

Ранее высказывалось мнение о том, что жертвенные комплексы «жеребец + кобыла» - комплексы с продуцирующей символикой, связанные с индоевропейскими мифами о браке с гиппоморфной богиней и ритуалами типа ашвамедхи [Zdanovich, Gayduchenko, 2002. P. 215-220].

В таблице 2 показано количественное распределение разных типов жертвенников с признаками/отсутствием колесничной символики и обозначены доминантные темы.

Таблица 2 Типология парных захоронений лошадей и доминирующие темы ритуала Table 2

Typology of the paired horse burials and most common ritual themes

\begin{tabular}{|c|c|c|c|c|c|}
\hline \multirow[t]{2}{*}{$\begin{array}{c}\text { Тип } \\
\text { жертвенника }\end{array}$} & \multicolumn{2}{|c|}{$\begin{array}{c}\text { Синташтинская культура, } \\
\text { признаки колесничного } \\
\text { комплекса }\end{array}$} & \multicolumn{2}{|c|}{$\begin{array}{c}\text { Петровская культура, } \\
\text { признаки колесничного } \\
\text { комплекса } \\
\end{array}$} & \multirow[t]{2}{*}{ Ритуальные темы* } \\
\hline & есть & нет & есть & нет & \\
\hline A1 & 7 & 4 & - & - & $\begin{array}{c}\text { колесничная, } \\
\text { плодородия }\end{array}$ \\
\hline A2 & 10 & 10 & 1 & - & $\begin{array}{c}\text { колесничная, } \\
\text { плодородия }\end{array}$ \\
\hline A3 & - & 2 & - & 1 & плодородия \\
\hline Б1 & 5 & 16 & - & 1 & $\begin{array}{l}\text { плодородия, } \\
\text { колесничная }\end{array}$ \\
\hline Б2 & - & - & 7 & 9 & $\begin{array}{c}\text { колесничная, } \\
\text { плодородия }\end{array}$ \\
\hline Б3 & - & - & - & 3 & плодородия \\
\hline
\end{tabular}

*Жирным шрифтом выделены доминантные темы

Как косвенное подтверждение связи ритуала погребения жертвенных лошадей с индоевропейским близнечным мифом можно рассматривать факт, что из всех жертвенных животных только лошади имеют погребальный инвентарь. ${ }^{4}$ В жертвенниках типа Б2 (мог. Берлик II, курган 10; мог. Аксайман, раскоп 4, яма 1) возле голов лошадей, как и в погребениях людей, поставлен сосуд. В погребении Синташтинского большого грунтового могильника под головой каждой лошади находилось по бронзовому ножу. Как своеобразный ин- вентарь можно рассматривать и псалии, сопутствующие лошадям в погребениях с колесницами. Интересное предположение позволяет сделать недавно выявленный факт: результаты радиоуглеродного датирования двух костяков лошадей из кургана 8 могильника Степное VII показали, что между жертвоприношениями двух особей прошел значительный промежуток времени [Епимахов и др., 2021]. Это может говорить о том, что в жертву приносили не любых, а конкретно связанных с погребенным лошадей и время их убоя опреде-

${ }^{3}$ Определения Л.Л. Гайдученко.

${ }^{4}$ Известны представления индоевропейцев о лошади, как существе, имеющем душу подобно человеку. 
лялось не нуждами единомоментного совершения ритуала, а обстоятельствами жизни лошади (болезнь, старость). Таким образом, при сроке жизни лошади 25-30 лет разница между временем их ритуального умерщвления могла быть довольно значительной.

Преобладание западной ориентировки костяков лошадей в жертвенниках типа Б2 можно трактовать как отражение мифологических представлений индоевропейцев о коне-солнце и западе как направлении, где расположена страна мёртвых, куда уходит заходящее солнце.

При всем сказанном следует отметить, что выделенные символические темы парных жертвоприношений воплощают внутренний конфликт: символика плодородия имеет отношение к воспроизведению жизненной силы, колесничная отражает тему войны и смерти. Говоря о парной символике в погребальном обряде в целом, и учитывая факты многочисленных пересечений тем парных погребений в «позе объятий» и парных жертвоприношений лошадей в синташтинской культуре, с одной стороны, и сосредоточения парных жертвоприношений лошадей в петровской культуре вокруг индивидуальных мужских погребений, с другой, можно предположить, что в синташтинской традиции темы «жизни» и «смерти» взаимно пересекаются и дополняются, тогда как в петровской - разделяются. Эти детали могут отражать как эволюцию мифологических сюжетов и религиозных представлений, так и некие социальные процессы, представленные в обряде в виде конфликта символов.

\section{Парность и дуализм}

\section{как мифологический сюжет}

Проявление символики парности в погребальных практиках археологических культур бронзового века Южного Зауралья и Казахстана находит истоки в специфике индоевропейских мифологических сюжетов, связанных с близнецами. Большинство исследователей относит племена, обитавшие в степной-лесостепной зоне Центральной Евразии, к древнейшим индоевропейцам, чему не противоречат последние данные исследований древнего генома жителей степей [Narasimhan et al., 2019]. Одним из подтверждений участия племен бронзового века в генезисе определенных индоевропейских народов могут служить проявления парности в погребальных обрядах (преимущественно синташтинской и петровской культур), сходные по семантике с индоевропейским близнечным мифом.

Основным характерным отличием индоевропейской близнечной мифологии является то, что мифологические представления, связанные с близнецами, в отличие от близнечных культов других народов, обладают сложной, но строгой системой. $\mathrm{y}$ народов других языковых семей обычно фиксируется не более одного мифа, в котором фигурирует близнечная пара богов/культурных героев, либо в мифологии такие персонажи отсутствуют вовсе, а близнечные культы проявляются в особом отношении к детям-близнецам. Для индоевропейских народов характерно иметь в рамках одной культурной традиции несколько мифов о разных близнечных парах. Так, в греческой мифологии фигурируют (либо близнечный аспект восстанавливается в подавленной архаической форме) близнечные пары Диоскуры, Молиониды, Аполлон и Артемида, Парис и Гектор, Геракл и Ификл. Установлено, что в архаическом варианте мифа братаблизнеца имел Прометей.

В индийской мифологии одними из наиболее известных пар являются Яма и Ями, Ашвины/Насатьи, Накула и Сахадева; в иранской мифологии - Ахурамазда и Ахриман, Машйа и Машйои. В таблице 3 представлена приблизительная структура индоевропейской близнечной мифологии и ее отличия от мифологии других народов.

Итак, мы можем констатировать, что близнечная мифология индоевропейских народов обладает рядом специфических, характерных только для неё черт и признаков, а именно:

- существование нескольких мифов о близнецах в рамках одной культурной традиции;

-отход от восприятия мифологических близнецов просто как воплощения суммы антитез;

-семантическая связь близнечной пары одновременно с двумя функциями/стратами - воинской (однополая пара, воины-колесничие/всадники) и производственной (разнополая пара, через связь однополой пары с Богиней-матерью);

-обязательная связь однополой пары с лошадьми/колесницами;

-при отсутствии отдельного мифа - существование особого отношения к детям-близнецам на уровне народных поверий и обрядов.

\section{Обсуждение и выводы}

Выявляемые проявления парной символики на погребальных памятниках культур эпохи бронзы Южного Зауралья и Казахстана многочисленны и разнообразны. Основную роль играют парные жертвоприношения лошадей, погребения с колесничной символикой и погребения в «позе объятия», являющиеся, как показывает анализ, двумя основными, достоверно устанавливаемыми моделями обряда, отражающими мифологические представления и обладающими высоким статусом. Объединённые вместе, проявления парности убедительно свидетельствуют о большой роли близнечных культов в мифологических представлениях изучаемых культур. Судя по статистическим данным, наиболее ярко данные мифологические представления проявлялись в синташтинской и петровской культурах. Их проявления в алакульских памятниках единичны и не обладают высоким сакральным статусом, что в целом соответствуют выявленной тенденции к упрощению и деградации погребального обряда в период поздней бронзы.

Комплексы, в которых, так или иначе, имитируется парная символика, находятся в целом в рамках соответствия с характерной символикой именно индоевропейского близнечного мифа, во- 
The structure of the Indo-European twins myth and its differences from the twins myth of other cultures

\begin{tabular}{|c|c|c|}
\hline $\begin{array}{c}\text { Близнечные персонажи } \\
\text { индоевропейской } \\
\text { мифологии } \\
\end{array}$ & Значение & $\begin{array}{c}\text { Отличия от мифологических } \\
\text { представлений неиндоевропейских } \\
\text { народов } \\
\end{array}$ \\
\hline $\begin{array}{l}\text { Разнополая близнечная } \\
\text { пара } \\
\text { Примеры: } \\
\text { Аполлон и Артемида, Яма } \\
\text { и Ями, Машйа и Машйои, } \\
\text { Фрейр и Фрейя [Иванов, } \\
\text { 1991; 1999] }\end{array}$ & $\begin{array}{l}\text { Символика разнополой пары во всех ин- } \\
\text { доевропейских мифах достаточно проста и } \\
\text { однозначна и связана с темами плодородия и } \\
\text { эротики [Иванов, 1991] }\end{array}$ & $\begin{array}{l}\text { В неиндоевропейской мифологии разнопо- } \\
\text { лые пары часто фигурируют в связи с дуаль- } \\
\text { но-фратриальной организацией общества, те- } \\
\text { мой соперничества полов, борьбы противопо- } \\
\text { ложностей [Золотарёв, 1964; Абрамян, 1991] }\end{array}$ \\
\hline $\begin{array}{l}\text { Однополая близнечная } \\
\text { пара } \\
\quad \text { Примеры: } \\
\text { Диоскуры, Молиониды, } \\
\text { Геракл и Ификл, Ашвины/ } \\
\text { Насатьи, } \\
\text { Накула и Сахадева, } \\
\text { Ахурамазда и Ахриман, } \\
\text { святые Фрол и Лавр, } \\
\text { Козьма и Демьян [Иванов, } \\
\text { 1991; Дудко, 2002; Дюмезиль, } \\
\text { 1986] }\end{array}$ & $\begin{array}{l}\text { В работах последователей Ж. Дюмезиля } \\
\text { однополые близнечные пары связываются со } \\
\text { второй (воинской) и третьей (производитель- } \\
\text { ной) функцией индоевропейского общества. } \\
\text { Однако примечательно, что в различных ми-- } \\
\text { фах близнецы фигурируют, как правило, либо } \\
\text { в одном из этих аспектов, либо обе функции } \\
\text { противопоставляются как антитеза. Таким } \\
\text { образом, в символике однополой пары пере- } \\
\text { плетаются два аспекта: } \\
\text { 1) тема плодородия; } \\
\text { 2) героические персонажи (близнецы-вои- } \\
\text { ны/цари) [Wikander, 1957; Ward, 1970] }\end{array}$ & $\begin{array}{l}\text { Отличительной чертой большинства индоев- } \\
\text { ропейских однополых близнечных пар является } \\
\text { их безусловная связь с лошадьми и колесница- } \\
\text { ми (однако некоторые данные указывают на ар- } \\
\text { хаическую связь с лошадьми также и разнопо- } \\
\text { лых пар). Мотив парных всадников/колесничих } \\
\text { встречается в скульптуре, иконописи, народной } \\
\text { вышивке многих индоевропейских народов. В } \\
\text { изобразительном искусстве (как и в мифологии) } \\
\text { часто медиатором, осью симметрии, связываю- } \\
\text { щей две фигуры всадников, является женщина } \\
\text { (Богиня) или Мировое Древо. Близнецы-всадни- } \\
\text { ки/колесничие т. о. связаны как с темой войны/ } \\
\text { власти, так и с темами плодородия и загробного } \\
\text { мира [Иванов, 1991; Иванов, Топоров, 1991; Дуд- } \\
\text { ко, 2002; Scott Littleton, 1970]. }\end{array}$ \\
\hline $\begin{array}{l}\text { Дети-близнецы } \\
\text { (отражение особого } \\
\text { отношения к близнецам } \\
\text { в народных обрядах и } \\
\text { поверьях) }\end{array}$ & $\begin{array}{l}\text { Если в мифологических текстах близнецы } \\
\text { выступают как символические фигуры, то } \\
\text { в народных обрядах и поверьях нашло отра- } \\
\text { жение отношение к близнецам биологиче- } \\
\text { ским. Большинство представлений связано с } \\
\text { детьми-близнецами (с одной стороны, потому } \\
\text { что близнецов труднее вырастить, и они реже, } \\
\text { чем обычные дети, доживали до зрелого воз- } \\
\text { раста, с другой - взрослые близнецы уже не } \\
\text { так похожи и не ассоциируются с одним нача- } \\
\text { лом, так как каждый, вырастая, начинает жить } \\
\text { своей судьбой). В большинстве народных по- } \\
\text { верий отражены представления о мифическом } \\
\text { происхождении близнецов и их необычайных } \\
\text { способностях (необходимости участия де- } \\
\text { тей-близнецов в некоторых обрядах, их спо- } \\
\text { собность к врачеванию и пр.) [Леви-Стросс, } \\
\text { 1994; Штернберг, 1936; Йеттмар, 1986] }\end{array}$ & $\begin{array}{l}\text { Особое отношение к детям-близнецам ха- } \\
\text { рактерно как для индоевропейских, так и } \\
\text { для других народов, но в мифологии народов } \\
\text { Африки, Америки, Сибири и пр. оно носит } \\
\text { скорее отрицательный характер - боязнь, } \\
\text { непонимание [Йеттмар, 1986; Тэрнер, 1983; } \\
\text { Штернберг, 1936] }\end{array}$ \\
\hline
\end{tabular}

площают и развивают темы, выделенные в индоевропейских мифологических сюжетах о Божественных Близнецах. Ядром близнечной символики бронзового века являются парные жертвоприношения лошадей. Специфической индоевропейской чертой было совмещзение продуцчирующей $и$ воинской символики в рамках одной модели, погребения, кургана:

-две темы, отражаемые в жертвенниках с парными лошадьми - «колесничная» и «продуцирующая», иногда совмещаемые;

- погребения в «позе объятия», иногда совмещающиеся с колесничной символикой;

- парные жертвоприношения коров, овец при колесничных комплексах и т. д.

Отдельно от обрядов, воплощающих основные черты мифов о Божественных Близнецах, отмечены редкие проявления особого отношения к близнецам биологическим: захоронения одновозрастных младенцев и жертвоприношения одновозрастных детёнышей домашних животных (предполагаемые близнецы), где особи/индивиды располагаются по принципу антитезы. Разделение в сфере народного сознания близнечных культов на почитание Божественных Близнецов, как одних из центральных фигур мифологии, и особое отношения к биологическим близнецам в сфере бытовой обрядности также характерно для индоевропейских племен.

В эпоху средней бронзы мы можем наблюдать, как внезапно появляются и занимают центральное место в погребальной обрядности синташтинской культуры комплексы, моделирующие близнечную символику в том виде, в котором она представлена в известных индоевропейских мифах. Эти процессы свидетельствуют о глобальных социальных трансформациях, происходивших в эпоху бронзы в степях-лесостепях Южного Зауралья и Казахстана - формировании элитных социальных страт, воплощавших, по крайней мере, на символическом уровне, военную и производственную функции.

Особого внимания заслуживает факт безусловного отличия характера парных жертвоприношений лошадей в синташтинских и петровских курганах. В настоящее время, по крайней мере, в отдельных регионах (в частности, на северной пе- 
риферии синташтинской культуры), на базе серии радиоуглеродных дат, полученных из памятников бронзового века в районе с. Степное Пластовского района Челябинской области зафиксированы неоспоримые свидетельства сосуществования синташтинского и петровского населения на одной территории [Епимахов и др, 2021]. Вполне вероятно, что две культурные группы, соседствуя, являлись двумя стратами одного общества, выполняющими различные функции. Отличия в характере парной символики в погребальном обряде в целом (пересечение и взаимное дополнение тем плодородия («жизни») и войны («смерти») в синташтинской обрядности и их разграничение в петровской) могут свидетельствовать о внутреннем идеологическом конфликте двух групп населения. Различия в типологии колесничных комплексов и парных жертвоприношений лошадей («частичные» жертвенники, приуроченные в основном к коллективным могилам в «синташте» и целые туши лошадей, располагающиеся у индивидуальных мужских погребений в «петровке»), в первом случае являются индикаторами принадлежности колесничной символики некоему коллективу (социальной группе, роду), во втором - говорят о формировании некоего подобия вождеской власти. Угасание этих ярких элементов обряда в дальнейшем (алакульские некрополи) - скорее о стратификации и возвращении к общинно-родовым формам общественного строя.

Приложение 1 Жертвоприношения лошадей и колесничный комплекс в погребальных памятниках бронзового века Урало-Казахстанских степей (синташтинская культура) Appendix 1

Horse sacrifices and the chariot assemblage in the Bronze Age burial sites on the territory of the Ural-Kazakhstan steppes (the Sintashta culture)

\begin{tabular}{|c|c|c|c|c|c|c|c|c|c|c|}
\hline \multirow{2}{*}{ 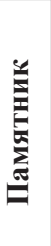 } & \multirow{2}{*}{ 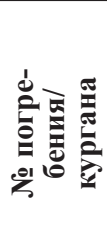 } & \multicolumn{2}{|c|}{$\begin{array}{c}\text { Количество } \\
\text { особей лошади } \\
\end{array}$} & \multicolumn{3}{|c|}{$\begin{array}{c}\text { Расположение } \\
\text { в погребении }\end{array}$} & \multirow[b]{2}{*}{ 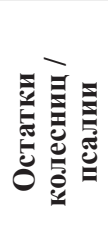 } & \multirow[b]{2}{*}{$\begin{array}{c}\text { Взаиморасположение } \\
\text { останков жертвенных } \\
\text { животных }\end{array}$} & \multirow{2}{*}{ 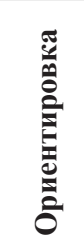 } & \multirow{2}{*}{ 焉 } \\
\hline & & $\begin{array}{l}\text { целые } \\
\text { туши }\end{array}$ & $\begin{array}{l}\text { голова- } \\
\text { ноги }\end{array}$ & $\begin{array}{l}\text { на пере- } \\
\text { крытии }\end{array}$ & $\begin{array}{c}\text { В } \\
\text { яме }\end{array}$ & $\begin{array}{l}\text { возле } \\
\text { погребе- } \\
\text { ния }\end{array}$ & & & & \\
\hline \multirow{9}{*}{ 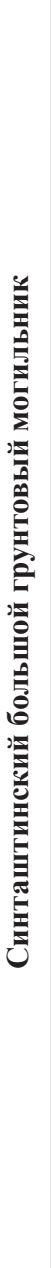 } & 2 & 4 & - & + & - & - & $-1-$ & $\begin{array}{c}\text { три костяка параллельно } \\
\text { друг другу, один костяк } \\
\text { перпендикулярно остальным }\end{array}$ & $\begin{array}{c}\mathrm{CCB} \\
\mathrm{C} 3\end{array}$ & Б1 \\
\hline & 3 & 2 & - & + & - & - & $-1-$ & $\begin{array}{c}\text { параллельно друг другу, один } \\
\text { на левом боку, } \\
\text { другой - на брюхе }\end{array}$ & C3 & Б1 \\
\hline & 4 & 4 & 2 & + & + & - & $+/-$ & по обе стороны дышла (?) & $\begin{array}{l}? \\
?\end{array}$ & $\begin{array}{l}\text { Б1 } \\
\text { A1 }\end{array}$ \\
\hline & 5 & 6 & $\begin{array}{l}1 \\
2\end{array}$ & + & + & $\begin{array}{l}- \\
- \\
- \\
-\end{array}$ & $+/+$ & $\begin{array}{c}\text { пара I - левый бок, } \\
\text { параллельно, } \\
\text { пара II - левый бок, } \\
\text { параллельно, } \\
\text { пара III - СВ угол (?) } \\
\text { по обе стороны дышла (?) }\end{array}$ & $\begin{array}{c}\text { Ю } \\
\text { C } \\
\text { B } \\
\text { ЮB } \\
?\end{array}$ & $\begin{array}{l}- \\
\text { Б1 } \\
- \\
- \\
\text { A1 }\end{array}$ \\
\hline & 6 & & 2 & - & - & - & $-1-$ & & $?$ & A1 \\
\hline & $10 / 16$ & 2 & 1 & $\begin{array}{l}+ \\
+\end{array}$ & - & - & $+1-$ & $\begin{array}{l}\text { на прав. боку, в позе } \\
\text { совокупления }\end{array}$ & $\stackrel{\mathrm{O}}{\mathrm{C}}$ & Б1 \\
\hline & 11 & & 2 & - & - & - & $-1+$ & $\begin{array}{c}\text { в нише м/д стенами ямы и } \\
\text { камеры } \\
\text { (вместе с черепом КРС) }\end{array}$ & CB & - \\
\hline & 12 & 4 & - & + & - & - & $+/+$ & $\begin{array}{c}\text { пара I: } \\
\text { I - правый бок, вдоль С стенки, } \\
\text { II - правый бок, вдоль С стенки } \\
\text { пара II: } \\
\text { III - левый бок, вдоль Ю } \\
\text { стенки, } \\
\text { IV - левый бок, вдоль Ю стенки } \\
\end{array}$ & $\begin{array}{l}\text { B } \\
3 \\
\\
\text { B } \\
3\end{array}$ & Б1 \\
\hline & 18 & 2(?) & - & + & - & - & $-1-$ & $\begin{array}{c}\text { на левом и правом боку, } \\
\text { мордами друг к другу }\end{array}$ & 3 & Б1 \\
\hline
\end{tabular}




\begin{tabular}{|c|c|c|c|c|c|c|c|c|c|c|}
\hline \multirow{2}{*}{ | } & \multirow{2}{*}{ 离 } & \multicolumn{2}{|c|}{$\begin{array}{c}\text { Количество } \\
\text { особей лошади } \\
\end{array}$} & \multicolumn{3}{|c|}{$\begin{array}{l}\text { Расположение } \\
\text { в погребении }\end{array}$} & \multirow{2}{*}{ 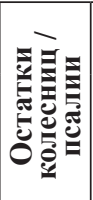 } & \multirow{2}{*}{$\begin{array}{c}\text { Взаиморасположение останков } \\
\text { жертвенных животных }\end{array}$} & \multirow{2}{*}{ 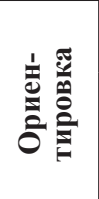 } & \multirow{2}{*}{ 窇 } \\
\hline & & $\begin{array}{l}\text { целые } \\
\text { туши }\end{array}$ & $\begin{array}{l}\text { голова- } \\
\text { ноги }\end{array}$ & $\begin{array}{l}\text { на пере- } \\
\text { крытии }\end{array}$ & $\begin{array}{l}\text { в } \\
\text { яме }\end{array}$ & $\begin{array}{l}\text { возле } \\
\text { погребе- } \\
\text { ния }\end{array}$ & & & & \\
\hline & 19 & 4 & - & + & - & - & $+/-$ & $\begin{array}{c}\text { пара I - левый и правый бок, мордами } \\
\text { друг к др., } \\
\text { пара II - левый и правый бок, морда- } \\
\text { ми друг к др. } \\
\end{array}$ & $\stackrel{\text { ЮB }}{\mathrm{C} 3}$ & Б1 \\
\hline & 22 & - & 1 & + & - & - & $-1-$ & восточная часть погребения & Ю & - \\
\hline & 24 & - & 2 & + & - & - & $-1-$ & в северной и в южной частях ямы & $?$ & $\mathrm{~A} 2$ \\
\hline & 25 & 2 & - & + & - & - & $-1-$ & 1 - правый бок, 2 - (?) & $?$ & Б1 \\
\hline & 26 & 2 & - & + & - & - & $-1-$ & $\begin{array}{c}\text { на левом боку, параллельно друг } \\
\text { другу }\end{array}$ & Ю3 & Б1 \\
\hline & 28 & $?$ & $?$ & $?$ & $?$ & $?$ & $+/-$ & $? ? ?$ & - & - \\
\hline & 29 & 2 & & + & & - & $-1-$ & $\begin{array}{c}\text { на левом и правом боку, параллельно } \\
\text { друг другу }\end{array}$ & C3 & Б1 \\
\hline & 30 & & 2 & & + & - & $+/+$ & по обе стороны дышла & Ю3 & $\mathrm{A} 1$ \\
\hline & 39 & $?$ & $?$ & $?$ & $?$ & $?$ & $-1+$ & $? ? ?$ & - & \\
\hline \multirow{6}{*}{ 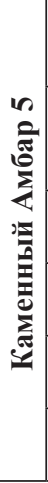 } & $\begin{array}{c}\text { К. } 2 \text {, } \\
\text { я. } 3\end{array}$ & 2 & $?$ & $\begin{array}{l}+ \\
+ \\
+\end{array}$ & - & - & $-1-$ & $? ? ?$ & - & $\mathrm{A} 2(?)$ \\
\hline & $\begin{array}{l}\text { К. } 2 \text {, } \\
\text { я. } 5 \\
\end{array}$ & $\begin{array}{l}1 \\
- \\
-\end{array}$ & $\begin{array}{l}1 \\
2 \\
\end{array}$ & $\begin{array}{l}+ \\
+ \\
+\end{array}$ & - & - & $\begin{array}{l}-1+ \\
-1-\end{array}$ & $\begin{array}{c}\text { скелет жеребенка и череп лошади - } \\
\text { возле Ю3 стенки } \\
2 \text { черепа лошади в В углу } \\
\end{array}$ & - & A2 \\
\hline & \begin{tabular}{|c|} 
К. 2 \\
я. 6 \\
\end{tabular} & - & 2 & + & - & - & $-1+$ & параллельно друг другу & ЮЮ3 & A2 \\
\hline & \begin{tabular}{|l|} 
K. 2, \\
я. 7 \\
\end{tabular} & - & 3 & - & + & - & $-1-$ & - & - & \\
\hline & \begin{tabular}{|c|} 
К. 2 \\
Я. 8 \\
\end{tabular} & - & 2 & - & + & - & $+/+$ & по обе стороны дышла & C3 & A1 \\
\hline & \begin{tabular}{|l|} 
К. 2, \\
я. 9 \\
\end{tabular} & 2 & - & $?$ & $?$ & - & $-1-$ & - & - & \\
\hline
\end{tabular}

\begin{tabular}{|c|c|c|c|c|c|c|c|c|c|c|}
\hline & $\begin{array}{l}\text { K. } 2, \\
\text { я. } 15\end{array}$ & & 2 & - & + & - & $-1-$ & параллельно друг другу & ЮЮ3 & $\mathrm{A} 1$ \\
\hline & $\begin{array}{l}\text { К. } 4, \\
\text { я. } 5\end{array}$ & $2(?)$ & & + & - & - & $? /-$ & $? ? ?$ & - & A2(?) \\
\hline & $\begin{array}{l}\text { К. } 4 \text {, } \\
\text { я. } 8\end{array}$ & - & $?$ & & - & - & $-/+$ & - & - & \\
\hline \multirow{5}{*}{ 苞 } & $\begin{array}{l}\text { К. } 4 \text {, } \\
\text { я. } 1\end{array}$ & - & 2 & + & - & - & $+/+$ & $\begin{array}{c}\text { параллельно друг другу, по обе } \\
\text { стороны дышла }\end{array}$ & C3 & A1 \\
\hline & $\begin{array}{c}\text { К. } 4, \\
\text { я.2 }\end{array}$ & - & 4 & - & + & - & $-1-$ & $\begin{array}{l}\text { Жертвенная яма: черепа параллельно } \\
\text { друг другу, конечности сверху }\end{array}$ & B & A3 \\
\hline & $\begin{array}{l}\text { К. } 5 \text {, } \\
\text { я. } 1\end{array}$ & - & 1 & + & & - & $-1-$ & Вост. угол & B & - \\
\hline & $\begin{array}{l}\text { К. } 5 \text {, } \\
\text { я. } 2\end{array}$ & - & - & - & - & - & $+/-$ & - & & - \\
\hline & $\begin{array}{l}\text { К. } 11, \\
\text { я. } 2\end{array}$ & - & 1 & - & + & - & $+/-$ & $\begin{array}{c}\text { Зап. угол (погребение ограблено, } \\
\text { возможна утрата черепа из С угла) }\end{array}$ & 3 & - \\
\hline \multirow{5}{*}{ 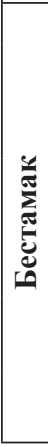 } & 1 & 2 & - & - & + & - & - & на брюхе, параллельно друг другу & 3 & Б1 \\
\hline & 5 & 3 & - & + & - & - & - & $\begin{array}{c}\text { пара I - параллельно, вдоль северной } \\
\text { и южной стен } \\
1 \text { лошадь вдоль восточной стенки } \\
\text { (все стоя) } \\
\end{array}$ & $\begin{array}{c}3 \\
\text { Ю }\end{array}$ & Б1 \\
\hline & 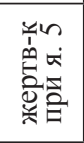 & - & 1 & - & + & - & - & $\begin{array}{c}\text { вместе с останками других животных } \\
\text { (1 особь КРС, } 1 \text { МРС, } 1 \text { жеребёнок) }\end{array}$ & - & - \\
\hline & 14 & - & 2 & - & + & - & - & $\begin{array}{c}\text { поверх остатков дистальных отделов } \\
\text { конечностей } 2 \text { особей МРС }\end{array}$ & - & A2 \\
\hline & $20-\mathrm{I}$ & 2 & - & + & - & - & - & $\begin{array}{l}\text { на левом и правом боку, } \\
\text { ногами друг к другу }\end{array}$ & - & Б1 \\
\hline & 20-II & 2 & - & + & - & - & - & $\begin{array}{c}\text { на левом и правом боку, } \\
\text { ногами друг к другу }\end{array}$ & - & Б1 \\
\hline & 22-A & 2 & - & + & - & - & - & $\begin{array}{c}\text { на левом и правом боку, } \\
\text { ногами друг к другу }\end{array}$ & - & Б1 \\
\hline & $22-Б$ & 2 & - & + & - & - & - & $\begin{array}{c}\text { на левом боку, } \\
\text { параллельно друг другу }\end{array}$ & - & Б1 \\
\hline
\end{tabular}




\begin{tabular}{|c|c|c|c|c|c|c|c|c|c|c|}
\hline \multirow{2}{*}{ 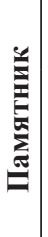 } & \multirow{2}{*}{ 番 } & \multicolumn{2}{|c|}{$\begin{array}{c}\text { Количество } \\
\text { особей лошади }\end{array}$} & \multicolumn{3}{|c|}{$\begin{array}{l}\text { Расположение } \\
\text { в погребении }\end{array}$} & \multirow{2}{*}{ 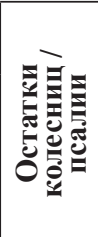 } & \multirow{2}{*}{$\begin{array}{c}\text { Взаиморасположение } \\
\text { останков жертвенных } \\
\text { животных }\end{array}$} & \multirow{2}{*}{ 递 } & \multirow{2}{*}{ 丞 } \\
\hline & & $\begin{array}{c}\text { целые } \\
\text { туши }\end{array}$ & $\begin{array}{c}\text { голова- } \\
\text { ноги }\end{array}$ & $\begin{array}{l}\text { на пере- } \\
\text { крытии }\end{array}$ & $\begin{array}{l}\text { в } \\
\text { яме }\end{array}$ & $\begin{array}{l}\text { возле } \\
\text { погребе- } \\
\text { ния }\end{array}$ & & & & \\
\hline & 26 & 2 & - & + & - & - & $-1-$ & $\begin{array}{c}\text { на левом и правом боку, } \\
\text { ногами друг к другу }\end{array}$ & - & Б1 \\
\hline & 35 & 2 & - & + & & - & $-1-$ & $\begin{array}{c}\text { на левом и правом боку, } \\
\text { ногами друг к другу }\end{array}$ & 3 & Б1 \\
\hline & 45 & 2 & - & - & + & - & $-1-$ & $\begin{array}{c}\text { на брюхе, параллельно } \\
\text { друг другу }\end{array}$ & 3 & Б1 \\
\hline \multirow{4}{*}{ 5) } & К. 24, я. 1 & - & $3(?)$ & - & + & - & $-1+$ & В Ю3 углу & $\mathrm{C}$ & A1 \\
\hline & К. 24, я. 2 & $?$ & $?$ & $?$ & $?$ & - & $-1+$ & $? ? ?$ & - & - \\
\hline & К. 25, я. 12 & - & 2 & + & - & - & $-1-$ & $\begin{array}{c}\text { Один череп в С3 углу, } \\
\text { второй - ? }\end{array}$ & Ю & $\mathrm{A} 2$ \\
\hline & К. 25, я. 24 & - & 2 & + & - & - & $-1-$ & $\begin{array}{c}\text { В С3 углу череп и ноги } \\
\text { особи 1, восточнее } \\
\text { выкладка костей особи } 2\end{array}$ & Ю3 & $\mathrm{A} 2$ \\
\hline & Я.1 & - & 2 & + & - & - & $-1-$ & $\begin{array}{l}\text { У южной стенки черепа } \\
\text { параллельно друг другу }\end{array}$ & Ю & $\mathrm{A} 2$ \\
\hline $\bar{U}$ & Я.2 & - & 4 & + & - & - & $-1-$ & $\begin{array}{c}\text { У ЮВ стенки два черепа } \\
\text { снизу, два сверху, мордами } \\
\text { в разные стороны } \\
\end{array}$ & 3 и В & $\mathrm{A} 2$ \\
\hline & Я. 3 & - & 1 & + & - & - & $-1-$ & $\begin{array}{c}\text { Останки жеребёнка в Ю } \\
\text { углу }\end{array}$ & 3 & $\mathrm{~A} 2$ \\
\hline & Я. 14 & $?$ & $?$ & $?$ & $?$ & - & $+(?) /+$ & $? ? ?$ & - & - \\
\hline & Я. 16 & - & 1 & + & - & - & $-1-$ & Вдоль западной стенки & $\mathrm{C}$ & $\mathrm{A} 2$ \\
\hline \multirow{3}{*}{ U } & Я. 1 & - & 2 & + & - & - & $-1+$ & У восточной стенки & $\mathrm{B}, \mathrm{CB}$ & $\mathrm{A} 2$ \\
\hline & Я. 5 & $1(?)$ & & + & - & - & $-1-$ & - & - & $?$ \\
\hline & Я. 7 & - & $1(?)$ & - & + & - & $-1-$ & У СВ стенки & - & A1(?) \\
\hline 元 & Я. 1 & - & $2(?)$ & - & + & - & $+/-$ & У южной стенки & $?$ & A1 \\
\hline \multirow{3}{*}{ שֶ } & К. 1 , я. 1 & - & 4 & + & - & - & $-1+$ & $\begin{array}{c}\text { На перекрытии: два } \\
\text { черепа с ногами у центра } \\
\text { С стенки, два - вдоль } \\
\text { южной в разрушенном } \\
\text { жертвеннике } \\
\end{array}$ & $\begin{array}{l}3 \\
?\end{array}$ & $\mathrm{~A} 2$ \\
\hline & К. 1 , я. 2 & - & 2 & + & - & - & $+/+$ & $\begin{array}{c}\text { На перекрытии в СВ и ЮВ } \\
\text { углах ямы }\end{array}$ & 3 & $\mathrm{~A} 2$ \\
\hline & К. 1 , я. 4 & - & 2 & - & + & - & $-1-$ & $\begin{array}{c}\text { Жертвенная. Черепа и } \\
\text { конечности двух лошадей } \\
\text { вместе с } 2 \text { особями КРС } \\
\text { параллельно друг другу } \\
\end{array}$ & $\mathrm{C} 3$ & $\mathrm{~A} 3$ \\
\hline \multirow{2}{*}{ 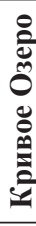 } & К. 9, я. 1 & - & 2 & + & - & - & $+/+$ & $\begin{array}{c}\text { У С стенки ямы } \\
\text { параллельно друг другу, } \\
\text { по обе стороны дышла }\end{array}$ & $\mathrm{C}$ & $\mathrm{A} 2$ \\
\hline & К. 9 , я. 2 & - & 2 & + & - & - & $-1+$ & У южной стенки & $?$ & $\mathrm{~A} 2$ \\
\hline \multirow{4}{*}{ 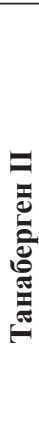 } & К. 7, п. 22 & - & $3(?)$ & + & - & - & $-1+$ & $\begin{array}{c}\text { В Ю3 углу - один череп с } \\
\text { ногами выше, два - ниже } \\
\text { него на перекрытии }\end{array}$ & $\mathrm{C} 3$ & $\mathrm{~A} 2$ \\
\hline & К. 7, п. 25 & - & 3 & + & - & - & $-1-$ & $\begin{array}{c}\text { Три черепа в ЮВ углу на } \\
\text { ступеньке }\end{array}$ & $\mathrm{C}$ & $\mathrm{A} 2$ \\
\hline & К. 7, п. 33 & - & 2 & + & - & - & $-1+$ & $\begin{array}{c}\text { На перекрытии в ЮВ } \\
\text { углу два черепа с ногами } \\
\text { вместе } \\
\end{array}$ & $\mathrm{CB}, 3$ & $\mathrm{~A} 2$ \\
\hline & К. 7, п. 36 & - & $1(?)$ & + & - & - & $-1-$ & $\begin{array}{c}\text { На перекрытии у Ю } \\
\text { стенки }\end{array}$ & $?$ & A2 \\
\hline
\end{tabular}


Приложение 2

Жертвоприношения лошадей и колесничный комплекс в погребальных памятниках бронзового века Урало-Казахстанских степей (петровско-алакульская группа) Appendix 2 Horse sacrifices and the chariot assemblage in the Bronze Age burial sites on the territory of the Ural-Kazakhstan steppes

\begin{tabular}{|c|c|c|c|c|c|c|c|c|c|c|}
\hline \multirow{3}{*}{ 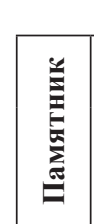 } & \multirow{3}{*}{ 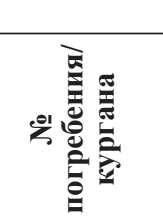 } & \multirow{2}{*}{\multicolumn{2}{|c|}{\begin{tabular}{|c|} 
Количество \\
особей лошади
\end{tabular}}} & \multirow{2}{*}{\multicolumn{3}{|c|}{$\begin{array}{l}\text { Расположение } \\
\text { в погребении }\end{array}$}} & \multirow{3}{*}{ 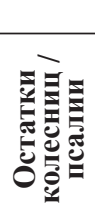 } & \multicolumn{3}{|c|}{ (the Petrovka-Alakul group) } \\
\hline & & & & & & & & & 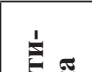 & \\
\hline & & $\begin{array}{l}\text { целые } \\
\text { туши }\end{array}$ & $\begin{array}{l}\text { голова- } \\
\text { ноги }\end{array}$ & $\begin{array}{l}\text { на пере- } \\
\text { крытии }\end{array}$ & $\begin{array}{c}\text { в } \\
\text { яме }\end{array}$ & $\begin{array}{l}\text { возле } \\
\text { погребе- } \\
\text { ния }\end{array}$ & & жертвенных животных & 常 & 急象象 \\
\hline \multirow{3}{*}{ 范 } & K. 1 & 2 & - & - & - & + & $-1-$ & $\begin{array}{c}\text { По краям длинных стен ямы, } \\
\text { ногами друг к другу }\end{array}$ & 3 & Б2.1 \\
\hline & K. 2 & 2 & - & - & - & + & $+/-$ & $\begin{array}{c}\text { По краям длинных стен ямы, } \\
\text { ногами в противоположные } \\
\text { стороны } \\
\end{array}$ & 3 & Б2.2 \\
\hline & K. 10 & 2 & - & - & - & + & $+/+$ & $\begin{array}{c}\text { На одном краю ямы, ногами друг } \\
\text { к другу } \\
\end{array}$ & 3 & Б2.3 \\
\hline \multirow{2}{*}{ 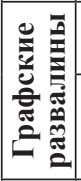 } & К. 15 & 2 & - & - & - & + & $-1-$ & $\begin{array}{c}\text { По краям длинных стен ямы, } \\
\text { ногами друг к другу }\end{array}$ & 3 & Б2.1 \\
\hline & К. 14 & 2 & - & - & - & + & $-1-$ & $\begin{array}{c}\text { На одном краю ямы, ногами друг } \\
\text { к другу }\end{array}$ & 3 & Б2.3 \\
\hline \multirow{2}{*}{ 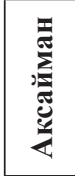 } & K. 2 & - & 2 & + & - & - & $+/+$ & $? ? ?$ & $?$ & A2 \\
\hline & K. 4 & 2 & - & - & - & + & $-1-$ & $\begin{array}{c}\text { По краям длинных стен ямы, } \\
\text { ногами в противоположные } \\
\text { стороны }\end{array}$ & 3 & Б2.2 \\
\hline \multicolumn{2}{|c|}{$\begin{array}{c}\text { Новоникольское, } \\
\text { к. } 1\end{array}$} & 2 & - & - & - & - & $-1-$ & $\begin{array}{l}\text { На одном краю ямы, ногами друг } \\
\text { к другу }\end{array}$ & 3 & Б2.3 \\
\hline \multicolumn{2}{|c|}{$\begin{array}{c}\text { Семипалатное, } \\
\text { к. } 2 \\
\end{array}$} & 2 & - & - & - & + & $-1-$ & $\begin{array}{c}\text { На одном краю ямы, ногами друг } \\
\text { к другу } \\
\end{array}$ & 3 & Б2.3 \\
\hline \multirow{3}{*}{ 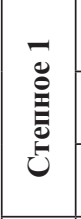 } & К. 5, я. 1 & 2 & - & - & & + & $-1-$ & $\begin{array}{c}\text { На одном краю ямы, ногами друг } \\
\text { к другу }\end{array}$ & 3 & Б2.3 \\
\hline & К. 5, я. 2 & - & 2 & - & + & & $-1-$ & $\begin{array}{c}\text { Жертвенная. Черепа параллельно } \\
\text { друг другу } \\
\end{array}$ & C-C3 & A3 \\
\hline & К. 8, я. 1 & 2 & - & - & - & + & $-1+$ & $\begin{array}{c}\text { Над С3 и Ю3 углами ямы, ногами } \\
\text { в одну сторону } \\
\end{array}$ & 3 & Б2.4(?) \\
\hline \multirow{4}{*}{ 异 } & К. 2 , я. 5 & - & - & - & - & - & $+/+$ & - & - & - \\
\hline & К. 4 , я. 18 & - & - & - & - & - & $+/+$ & - & - & - \\
\hline & К.7, я. 85 & 2 & - & - & + & - & - & $\begin{array}{c}\text { Целая туша и части второй в } \\
\text { отдельной яме }\end{array}$ & Ю3 & Б3 \\
\hline & К. 8, я. 1 & 2 & - & + & - & - & $-1-$ & $\begin{array}{c}\text { На перекрытии ногами друг к } \\
\text { другу }\end{array}$ & 3 & Б1 \\
\hline \multicolumn{2}{|c|}{ Нуртай, к.2 } & 2 & - & - & - & - & $-1-$ & $\begin{array}{c}\text { На одном краю ямы, ногами друг } \\
\text { к другу } \\
\end{array}$ & 3 & Б2.3 \\
\hline \multirow{4}{*}{ 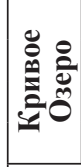 } & К. 1 , я. 1 & $?$ & - & - & & + & $-/+$ & - & - & - \\
\hline & К. 1, я. 2 & $?$ & - & - & & + & $-1+$ & - & - & - \\
\hline & К. 1, я. 3 & $?$ & - & - & & + & $-1+$ & - & - & - \\
\hline & К. 2, я. 1 & - & $?$ & - & & + & $+/+$ & - & - & - \\
\hline \multicolumn{2}{|c|}{$\begin{array}{l}\text { Аяпберген, } \\
\text { к.7, я.1 }\end{array}$} & 2 & - & - & - & + & $-1-$ & $\begin{array}{c}\text { На краю у } 3 \text { стенки ямы, ногами } \\
\text { в разные стороны }\end{array}$ & 3 & Б2.4 \\
\hline \multirow{2}{*}{ 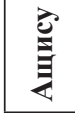 } & К. 1 , я. 2 & 2 & - & - & - & + & $-/+$ & На краю у Ю стенки ямы & 3 & Б2.4 \\
\hline & К. 1 , я. 1 & $2(?)$ & - & - & - & + & $-1+$ & На краю у Ю стенки ямы & 3 & Б2.4(?) \\
\hline \multicolumn{2}{|c|}{$\begin{array}{l}\text { Хрипуновский, } \\
\text { я. } 16\end{array}$} & 2 & - & - & + & - & $-1-$ & $\begin{array}{c}\text { В отдельной яме, головами и } \\
\text { ногами друг к другу }\end{array}$ & C3 & Б3 \\
\hline \multirow{2}{*}{ 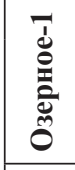 } & K. 7 & $?$ & - & - & - & - & $+/-$ & - & - & - \\
\hline & К. 8 & 2 & - & - & - & + & $-1-$ & $\begin{array}{c}\text { Вдоль С и Ю стенок ямы, ногами } \\
\text { в одну сторону(?) }\end{array}$ & 3 & Б2.2(?) \\
\hline \multirow{4}{*}{ 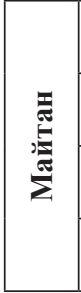 } & Огр.7 & 2 & - & - & - & + & - & $\begin{array}{c}\text { На краях ямы, ногами в одну } \\
\text { сторону }\end{array}$ & Ю3 & Б2.1(?) \\
\hline & Огр.15 & 2 & - & - & - & + & - & $\begin{array}{c}\text { Целая туша и ноги на площадке } \\
\text { возле погр. }\end{array}$ & Ю & - \\
\hline & Огр.29В & 2 & - & - & - & + & + & $\begin{array}{c}\text { По краям ямы ногами друг к } \\
\text { другу }\end{array}$ & C3 & Б2.1 \\
\hline & Огр.29Г & 2 & - & - & - & + & - & $\begin{array}{c}\text { По одну сторону ямы ногами } \\
\text { друг к другу }\end{array}$ & 3 & Б2.3 \\
\hline
\end{tabular}




\section{СПИСОК ЛИТЕРАТУРЫ}

АбрамянЛ.А. Мир мужчин и мир женщин: расхождение и встреча // Этнические стереотипы мужского и женского поведения. СПб.: Наука, 1991. C. 109-131.

Берсенева Н.А. «Семейные» (?) погребения синташтинской культуры (эпоха бронзы Южного Урала) // Казахское ханство в потоке истории: Сб. науч. ст., посвященный 550-летию образования Казахского ханства / Гл. ред. Б.А. Байтанаев. Алматы: Институт археологии им. А.Х. Маргулана, 2015. C. 335-341.

Боталов С.Г., ГригорьевС.А., ЗдановичГ.Б. Погребальные комплексы эпохи бронзы Большекараганского могильника (публикация результатов археологических раскопок 1988 года) // Материалы по археологии и этнографии Южного Урала / Науч. ред. А.Д. Таиров. Челябинск: Каменный пояс, 1996. С. 64-88. (Труды музея-заповедника Аркаим)

Бочкарёв В.С., Кузнечов П.Ф. Основные этапы развития щитковых псалиев Северной Евразии // Процесс культурогенеза начальной поры позднего бронзового века Волго-Уральского региона (вопросы хронологии, периодизации, историографии). Материалы междунар. науч. конф. 12-14 мая 2014 г. Самара: ПГСГА, 2014. С. 5-10.

ВасильевИ.Б. Могильник ямно-полтавкинского времени у с.Утевка в Среднем Поволжье // Вопросы археологии Поволжья. Вып. 5 / Отв. ред. М.А. Турецкий. Самара: СамНЦ РАН, 2015. C. 4-46.

Виноградов Н.Б. Могильник бронзового века Кривое Озеро в Южном Зауралье. Челябинск: Южно-Уральское кн. изд-во, 2003. 362 с.

ГенингВ.Ф., Зданович Г.Б., Генинг В.В. Синташта: Археологические памятники арийских племён Урало-Казахстанских степей. Ч. 1. Челябинск: Южно-Уральское кн. изд-во, 1992. 408 с.

Дудко Д.М. Парные боги-всадники у славян и иранское влияние // Восток. № 5. 2002. С. 5-16.

ДюмезильЖ. Верховные боги индоевропейцев. М.: Наука, 1989. 234 с.

Eпимахов A.B. Курганный могильник Солнце II - некрополь укреплённого поселения Устье эпохи средней бронзы // Материалы по археологии и этнографии Южного Урала / Науч. ред. А.Д.Таиров. Челябинск: Каменный пояс, 1996. С.22-42. (Труды музея-заповедника Аркаим)

Eпимахов A.B. К вопросу о «деградации» колесничного комплекса в период поздней бронзы в Южном Зауралье (по материалам могильника Николаевка II) // Вестник ЧГПУ. Серия 1. Исторические науки. Вып. 2. 2004. С. 105-111.

Епимахов А.В. Ранние комплексные общества севера Центральной Евразии (по материалам могильника Каменный Амбар-5). Кн. 1. Челябинск: Челябинский дом печати, 2005. $192 \mathrm{c}$.

Епимахов А.В., КуприяноваЕ.В., ХоммельП.,
Хэнкс Б.К. От представлений о культурной эволюции к мозаике культурных традиций (бронзовый век Урала в свете больших серий радиоуглеродных дат) // Материалы I Междунар. междисциплинарной конф. «Древние и традиционные культуры во взаимодействии со средой обитания: проблемы исторической реконструкции». Челябинск: ЧелГУ, 2021. C. 7-29.

Епимахов А.В., Новиков И.К. Проблема интерпретации колесничной символики бронзового века в лесостепном Зауралье (по материалам могильника Озерное-1) // Археологические вести. Вып. 23. 2017. C. 345-354.

ЗдановичД.Г. Археология кургана 25 Большекараганского могильника // Аркаим: некрополь (по материалам кургана 25 Большекараганского могильника. Челябинск: Южно-Уральское кн. изд-во, 2002. С. 17-106.

ЗдановичД.Г., КуприяноваЕ.В. Парные жертвоприношения лошадей в бронзовом веке Центральной Евразии: археология, мифология и ритуал // Происхождение и распространение колесничества / Отв. ред. А.Н. Василенко. Луганск: Глобус, 2008. С. $188-197$.

Зданович Д.Г., Куприянова Е.В. Лошади и Близнецы: к «археологии ритуала» Центральной Евразии эпохи бронзы // Аркаим-Синташта: древнее наследие Южного Урала. К 70-летию Г.Б. Здановича: сборник науч. трудов. Ч. 1 / Отв. ред. Д.Г.Зданович. Челябинск: ЧелГУ, 2010. С. 130-161.

Золотарев А.М. Родовой строй и первобытная мифология. М.: Наука, 1964. 328 с.

Иванов Вяч.Bc. Близнечные мифы // Мифы народов мира. Т. 1. М.: Советская Энциклопедия, 1991. С. 174-176.

Иванов Вяч.Вс. Нечет и чет // Избранные труды по семиотике и истории культуры. Т. 1. М.: Языки русской культуры, 1999. С. 381-602.

Иванов Вяч. Вс., Топоров В.Н. Индоевропейская мифология // Мифы народов мира. Т. 1. М.: Советская Энциклопедия, 1991. С. 527-533.

Йеттмар К. Религии Гиндукуша. М.: Наука, $1986.524 \mathrm{c}$.

Кукушкин И.А. Могильник Аяпберген - раннеандроновский памятник Центрального Казахстана // Изучение памятников археологии Павлодарского Прииртышья. Вып. 2 / Отв. ред. В.К. Мерц. Павлодар: ЭКО, 2006. С. 50-69.

Кукушкин И.А. Археологические исследования могильника Ащису. Курган 1 // Историко-культурное наследие Сарыарки / Отв. ред. В.Г. Ломан. Караганда: КарГУ им. Е.А. Букетова, 2007. С.4064.

Куприянова Е.В. Погребальные практики эпохи бронзы Южного Зауралья: могильник Степное-1 (раскопки 2008, 2010-2011, 2014 гг.). Челябинск: Энциклопедия, 2016. 119 c.

Куприянова Е.В. «Мужская» и «женская» мо- 
дель в погребальной обрядности бронзового века в Южном Зауралье // Мужской и женский мир в отражении археологии. Материалы всерос. с междунар. участием конф. в г.Уфа 19-22 ноября 2018 г. Уфа: ИИЯЛ УФИЦ РАН, 2018. С. 33-43.

КуприяноваЕ.В., ЗдановичД.Г. Древности лесостепного Зауралья: могильник Степное VII. Челябинск: Энциклопедия, 2015. $196 \mathrm{c.}$

КуприяноваЕ.В., УсачукА.Н. Псалии могильника Степное 1: практический и семантический аспекты использования // Archaeoastronomy and Ancient Technologies. № 8(1). 2020. C. 69-100.

Леви-Стросс К. Первобытное мышление. М.: Республика, 1999. 392 с.

Логвин А.В. Синташтинско-петровские древности Тургайского прогиба. Дисс. ... канд. ист. наук. Кемерово, 2019. 429 с.

Матвеев А.В. Первые андроновцы в лесах Зауралья. Новосибирск: Наука, 1998. 417 с.

Михайлова О.В., КузьминаО.В. Новые памятники эпохи бронзы в Самарском Поволжье // Oxрана и изучение памятников истории и культуры в Самарской области. Вып. 1 / Сост. Д.А. Сташенков. Самара: СОИКМ, 1999. С.98-141.

Новожёнов В.A. Наскальные изображения повозок Средней и Центральной Азии. Алматы: Аргументы и факты Казахстан, 1994. 297 с.

Потёмкина Т.M. Бронзовый век лесостепного Притоболья. М.: Наука, 1985. 375 с.

ПьсларуИ.А. Индоевропейцы, конь и узда в эпоху бронзы // Stratum plus. №2. 2000. С.322345.

РафиковаЯ.В. Парные погребения алакульской культуры на Южном Урале // Арии степей Евразии: эпоха бронзы и раннего железа в степях Евразии и на сопредельных территориях: Сб. памяти Е.Е. Кузьминой. Барнаул: АлтГУ, 2014. C. 228-243.

Сальников К.В. Курганы на озере Алакуль // МИА. 1952. № 24. С. 51-71.

Сотникова C.B. К вопросу о парных захоронениях лошадей в колесничных культурах эпохи бронзы: реконструкция ритуалов и представлений (по материалам памятников синташтинского и петровского типа // Проблемы истории, филологии, культуры. 2014a. № 2(44). С. 176-189.

Сотникова C.B. Образ колесницы и колесничего в ритуальной практике населения эпохи бронзы Евразийских степей: опыт реконструкции ритуала и представлений // Вестник Томского государственного университета. 2014б. №380. C. 102-108.

Сотникова С.В. К вопросу о синташтинской традиции парных захоронений лошадей // Археология Северной и Центральной Азии: новые открытия и результаты междисциплинарных исследований. Сборник статей, посвящ. 75-летию профессора Ю.Ф.Кирюшина / Отв. ред. А.А. Тишкин. Барнаул: АлтГУ, 2021. С. 175-179.

ТереножкинА.И., МозолевскийБ.Н. Мелитопольский курган. Киев: Наукова думка, 1988. $264 c$.
Ткачёв А.А. Центральный Казахстан в эпоху бронзы. Ч. 1. Тюмень: ТюмГНГУ, 2002. 289 с.

Ткачёв А.А. Могильник эпохи бронзы Майтан. Новосибирск: СО РАН, 2019. 529 с.

Ткачёв В.В. Степи Южного Приуралья и Западного Казахстана на рубеже эпох средней и поздней бронзы. Актобе: Актюбинский областной центр истории, этнографии и археологии, 2007. 384 c. $277 \mathrm{c}$

Тэрнер В. Символ и ритуал. М.: Наука, 1983.

Усачук А.Н. Древнейшие псалии (изготовление и использование). Киев, Донецк: ИА НАНУ, 2013. 304c.

ЧерленокЕ.А. Погребения колесничих лошадей в позднем бронзовом веке на территории Восточной Европы и Казахстана // Stratum plus. № 2. 2000. С. 346-349.

ЧерленокЕ.А. Колесничная запряжка в погребальном обряде (начало эпохи поздней бронзы Евразийских степей) // Вестник молодых ученых. Сер. Исторические науки. № 1. 2001. С. 22-29.

Чечушков И.В. Колесницы евразийских степей эпохи бронзы // Вестник археологии, антропологии и этнографии. Вып. 2(15). 2011. С. 57-65.

Чечушков И.В. Колесничный комплекс эпохи поздней бронзы степной и лесостепной Евразии (от Днепра до Иртыша). Автореф. дис. ... канд. ист. наук. М., 2013. 26 с.

ЧечушковИ.В., ЕпимаховА.В. Колесничный комплекс Урало-Казахстанских степей // Кони, колесницы и колесничие степей Евразии. Коллективная монография / Гл. ред. П.Ф. Кузнецов. Екатеринбург, Самара, Донецк: Рифей, 2010. С. 182229.

ШтернбергЛ.Я. Первобытная религия в свете этнографии. Л.: Наука, 1936. 571 с.

Day L.P. Dog burials in the Greek world // American journal archaeology . Vol. 88. № 1. 1984. P. 2132.

KupriyanovaE., EpimakhovA., BersenevaN., BersenevA. Bronze Age Charioteers of the Eurasian Steppe: A Part-time Occupation for Select Men? // Praehistorische Zeitschrift. № 92(1). 2017. P. 40-65.

MakkayJ. Mycenaean burial sacrifices and the origins of the Proto-Greeks // Atti e Memorie del Secondo Congresso Internazionale de Micenologia, Roma - Napoli 1991. 1996. Roma. P. 777-784.

NarasimhanV.M., PattersonN., MoorjaniP., RohlandN., Bernardos R., MallickS., Lazaridis I., NakatsukaN., et al. The formation of human population in South and Central Asia // Science. 365. Eaat7487 (2019). September, 2019. P.341. DOI: 10.1126/science.aat 7487

Scott Littleton C. Some possible Indo-European themes in the Iliad // Myth and Law among the IndoEuropeans. Berkley; Los Angeles; London: University of California press, 1970. P. 229-246.

VanderpoolE. New letter from Greece // American journal archaeology. 1959. Vol.63. № 3. P. 279283.

Vermeule E. Aspects of death in early Greek art 
and poetry. Berkeley; Los Angeles; London: University of California Press, 1979. 270 p.

Ward $D$. The separate function of the Indo-European Divine Twins // Myth and Law among the Indo-Europeans. Berkley; Los Angeles; London, 1970. P. 193-202.
WikanderS. Nakula et Sahadeva // Orientalia Suecana. 6. 1957. P. 66-96.

ZdanovichD.G., GayduchenkoL.L. Sintashta burial sacrifice: The Bolshekaragansky cemetery in focus // Complex societies of Central Eurasia from the $3^{\text {rd }}$ to the $1^{\text {st }}$ Millenium BC: Regional specifics in light of global models. Washington DC, 2002. Vol. I. P. 202-231.

\section{REFERENCES}

Abramyan, L.A. "The world of men and the world of women: divergences and synergies", Etnicheskie stereotipy muzhskogo i zhenskogo povedeniya ("Ethnic stereotypes of male and female behavior"). St. Petersburg, 1991, pp. 109-131. (In Russ.)

Berseneva, N.A. "Family" (?) burials of the Sintashta culture (the Bronze Age in the Southern Urals)", Kazahskoe hanstvo v potoke istorii: Sbornik nauchnyh statej, posvyashchennyj 550-letiyu obrazovaniya Kazahskogo hanstva ("The Kazakh Khanate in the flow of history: Collection of scientific papers dedicated to the $550^{\text {th }}$ anniversary of the formation of the Kazakh Khanate"). Almaty, 2015, pp.335-341. (In Russ.)

Botalov, S.G., Grigoriev, S.A., \& Zdanovich, G.B. "Burials of the Bronze Age of Bolshekaragansky necropolis (results of the archaeological excavations in 1988)", Materialy po arheologii i etnografii Yuzhnogo Urala ("Materials on the archeology and ethnography of the Southern Urals"). Chelyabinsk, 1996, pp.6488. (In Russ.)

Bochkarev, V.S., Kuznetsov, P.F. The main stages of the development of shield cheek-pieces of Northern Eurasia, Process kul'turogeneza nachal'noj pory pozdnego bronzovogo veka Volgo-Ural'skogo regiona (voprosy hronologii, periodizacii, istoriografii). Materialy mezhdunarodnoj nauchnoj konferencii 12-14 maya $2014 \mathrm{~g}$. ("The process of cultural genesis of the first stage of the Late Bronze Age in the Volga-Ural region (questions of chronology, periodization, historiography. Proceedings of the international scientific conference May 12-14, 2014”). Samara, 2014, pp. 5-10. (In Russ.)

Vasiliev, I.B. 2015, "Necropolis of the YamnayaPoltavka times near the village of Utevka in the Middle Volga region", Voprosy arheologii Povolzh'ya, iss. 5, pp. 4-46. (In Russ.)

Vinogradov, N.B. 2003, The Bronze Age necropolis Krivoe Ozero in the Southern Trans-Urals region. Yuzhno-Ural'skoe kn. izd-vo, Chelyabinsk, 362 p. (In Russ.)

Gening, V.F., Zdanovich, G.B., \& Gening, V.V. 1992, Sintashta: Archaeological sites of the Aryan tribes of the Ural-Kazakhstan steppes. Part 1. Yuzhno-Ural'skoe kn. izd-vo, Chelyabinsk, 408p.

Dudko, D.M. 2002, "Paired gods-riders among the Slavs and the Iranian influence", Vostok, no.5, pp. 5-16. (In Russ.)

Dumezil, J. 1989, The supreme gods of the IndoEuropeans. Nauka, Moscow, 234 p. (In Russ.)

Epimakhov, A.V. "Barrow cemetery Solntse II - a necropolis of the fortified Medieval settlement
Ust'ye", Materialy po arheologii i etnografi Yuzhnogo Urala ("Materials on the archeology and ethnography of the Southern Urals"). Chelyabinsk, 1996, pp. 22-42. (In Russ.)

Epimakhov, A.V. 2004, "On the question of the "degradation" of the chariot complex in the Late Bronze Age in the Southern Trans-Urals (based on the assemblages from Nikolaevka II necropolis)", Vestnik $C G P U$, iss. 2, pp. 105-111. (In Russ.)

Epimakhov, A.V. 2005, "Early complex societies in the Northern part of Central Eurasia (based on the assemblages from Kamenny Ambar-5 necropolis). Vol. 1." Chelyabinskij dom pechati, Chelyabinsk, 192 p. (In Russ.)

Epimakhov, A.V., Kupriyanova,E.V., \& Hommel, P., Hanks, B.K. "From the ideas about cultural evolution to the mosaic of cultural traditions (the Bronze Age Urals in the light of a large series of radiocarbon dates)", Materialy I Mezhdunarodnoj mezhdisciplinarnoj konferencii "Drevnie $i$ tradicionnye kul'tury vo vzaimodejstvii so sredoj obitaniya: problemy istoricheskoj rekonstrukcii) ("Proceedings of the $1^{\text {st }}$ International Interdisciplinary Conference "Ancient and traditional cultures and their interactions with the environment: problems of historical reconstruction"). Chelyabinsk, 2021, pp. 7-29. (In Russ.)

Epimakhov, A.V., Novikov, I.K. 2017, “The problem of interpretation of the chariot symbolism of the Bronze Age in the forest-steppe Trans-Urals (based on the assemblages from Ozernoye-1 necropolis", Archaeological News, no.23, pp. 345-354. (In Russ.)

Zdanovich, D.G. "Archeology of barrow 25 of Bolshekaragansky necropolis", Arkaim: nekropol' (po materialam kurgana 25 Bol'shekaraganskogo mogil'nika) ("Arkaim: necropolis (based on the assemblages from barrow 25 of Bolshekaragansky cemetery)"). Chelyabinsk, 2002, pp. 17-106. (In Russ.)

Zdanovich D.G., Kupriyanova E.V. "Double horse sacrifices dated to the Bronze Age in Central Eurasia: archeology, mythology and ritual", Proiskhozhdenie $i$ rasprostranenie kolesnichestva ("The origins and spread of chariots"). Lugansk, 2008, pp. 188-197. (In Russ.)

Zdanovich, D.G., Kupriyanova, E.V. "Horses and Twins: to the "archeology of the ritual" of Central Eurasia in the Bronze Age", Arkaim-Sintashta: drevnee nasledie Yuzhnogo Urala. K 70-letiyu G.B. Zdanovicha: sbornik nauchnyh trudov ("Arkaim-Sintashta: the ancient heritage of the Southern Urals. To the $70^{\text {th }}$ anniversary of G.B. Zdanovich: a collection of scientific papers. Part 1"). Chelyabinsk, 2010, pp. 130-161. (In Russ.) 
Zolotarev,A.M. 1964, Clan society and the primitive mythology. Nauka, Moscow, $328 \mathrm{p}$. (In Russ.)

Ivanov, V.V. "Twin myths", Mify narodov mira ("Myths of the peoples of the world. Vol. 1"). Moscow, 1991, pp. 174-176. (In Russ.)

Ivanov, V.V. "Odd and even", Izbrannye trudy po semiotike $i$ istorii kul'tury ("Selected works on semiotics and cultural history"). Moscow, 1999, pp. 381-602. (In Russ.)

Ivanov, V.V., Toporov, V.N. "Indo-European mythology", Mify narodov mira ("Myths of the peoples of the world"). Moscow, 1991. pp. 527-533. (In Russ.)

Yettmar, K. 1986, Religions of the Hindu Kush. Nauka, Moscow, 524 p. (In Russ.)

Kukushkin, I.A. "Ayapbergen necropolis - a site of the early Andronovo culture in Central Kazakhstan", Izuchenie pamyatnikov arheologii Pavlodarskogo Priirtysh'ya ("The study of archaeological sites of the Irtysh river region near Pavlodar"). Pavlodar, 2006, pp. 50-69. (In Russ.)

Kukushkin, I.A. "Archaeological study of Ashchisu necropolis. Barrow 1", Istoriko-kul'turnoe nasledie Saryarki ("Historical and cultural heritage of Saryarka"). Karaganda, 2007, pp.40-64. (In Russ.)

Kupriyanova,E.V. 2016, Funerary rites of the Bronze Age in the Southern Trans-Urals: Stepnoye-1 necropolis (excavations 2008, 2010-2011, 2014). Encyclopedia, Chelyabinsk, 119 p. (In Russ.)

Kupriyanova,E.V. "Male" and "female" models in the funerary rites of the Bronze Age in the Southern Trans-Urals", Muzhskoj $i$ zhenskij mir v otrazhenii arheologii. Materialy vseros. s mezhdunar. uchastiem konf. v g. Ufa 19-22 noyabrya $2018 \mathrm{~g}$. ("Male and female world as reflected by archeology. Proceedings of the All-Russian conference with foreign participants, Ufa, November 19-22 2018"). Ufa, 2018, pp. 33-43. (In Russ.)

Kupriyanova, E.V., Zdanovich, D.G. 2015, Antiquities of the forest-steppe Trans-Urals: Stepnoye VII necropolis. Encyclopedia, Chelyabinsk, 196 p. (In Russ.)

Kupriyanova,E.V., Usachuk, A.N. 2020, "Cheek-pieces from Stepnoye 1 necropolis: practical and semantic aspects of use", Archeoastronomy and Ancient Technologies, no. 8(1), pp.69-100. (In Russ.)

Levi-Strauss, K. 1999, Primitive mentality. Republic, Moscow, 392 p. (In Russ.)

Logvin, A.V. 2019, Sintashta-Petrovka antiquities of the Turgai trough. Dissertation... Candidate of Historical Sciences. Kemerovo, 429 p. (In Russ.)

Matveev, A.V. 1998, The first Andronovo tribes in the forests of the Trans-Urals. Nauka, Novosibirsk, 417 p. (In Russ.)

Mikhailova, O.V., Kuzmina, O.V. "New sites of the Bronze Age in the Volga river region near Samara", Ohrana i izuchenie pamyatnikov istorii i kul'tury $v$ Samarskoj oblasti ("Preservation and study of his- torical and cultural sites in the Samara region"). Samara, 1999, pp.98-141. (In Russ.)

Novozhenov, V.A. 1994, Rock paintings of carts in Central Asia. Argumenty i fakty Kazahstan, Almaty, 297 p. (In Russ.)

Potemkina, T.M. 1985, The forest-steppe Tobol river region in the Bronze Age. Nauka, Moscow, 375 p. (In Russ.)

Pyslaru, I.A. 2000, "Indo-Europeans, horse and bridle in the Bronze Age", Stratum plus, no.2, pp. 322-345. (In Russ.)

Rafikova, Y.V. "Double burials of the Alakul culture in the Southern Urals", Arii stepej Evrazii: epoha bronzy i rannego zheleza $v$ stepyah Evrazii $i$ na sopredel'nyh territoriyah ("Aryan of the steppes of Eurasia: the steppes of Eurasia and the adjacent territories in the Bronze and Early Iron Age"). Barnaul, 2014, pp. 228-243. (In Russ.)

Salnikov, K.V. 1952, "Barrows near lake Alakul”, MIA, no. 24, pp. 51-71. (In Russ.)

Sotnikova, S.V. 2014, "To the question of the double horse burials in the Bronze Age chariot cultures: reconstruction of the rituals and beliefs (based on the assemblages from the sites of the Sintashta and Petrovka type)", Problems of history, philology and culture, no. 2(44), pp.176-189. (In Russ.)

Sotnikova, S.V. 2014, "Images of chariots and charioteers in the rituals of the Bronze Age population of Eurasian steppes (reconstruction of rites and beliefs)", Tomsk State University Journal, no.380, pp. 102-108. (In Russ.)

Sotnikova, S.V. "To the questions of the Sintashta tradition of double horse burials", Arheologiya Severnoj i Central'noj Azii: novye otkrytiya $i$ rezul taty mezhdisciplinarnyh issledovanij ("Archaeology of North and Central Asia: recent discoveries and results of the interdisciplinary studies"). Barnaul, 2021, pp. 175-179. (In Russ.)

Terenozhkin, A.I., $\quad$ Mozolevsky, B.N. 1988, Melitopol barrow. Naukova Dumka, Kiev, 264 p. (In Russ.)

Tkachev, A.A. 2002, Central Kazakhstan in the Bronze Age. Part 1. TumGNGU, Tyumen, $289 \mathrm{p}$. (In Russ.)

Tkachev, A.A. 2019, Maitan - a necropolis of the Bronze Age period. SO RAN, Novosibirsk, $529 \mathrm{p}$. (In Russ.)

Tkachev V.V. 2007, Steppes of the Southern CisUrals and Western Kazakhstan at the turn of the Middle and Late Bronze Ages. Aktyubinskij oblastnoj centr istorii, etnografii i arheologii, Aktobe, $384 \mathrm{p}$. (In Russ.)

Terner, V. 1983, Symbol and ritual. Nauka, Moscow, 277 p. (In Russ.)

Usachuk, A.N. 2013, The oldest cheek-pieces (production and use). IA NANU, Kiev, Donetsk, 304 p. (In Russ.)

Cherlenok, E.A. 2000, "Burials of chariot horses of the Late Bronze Age on the territory of Eastern Europe and Kazakhstan", Stratum plus, no.2, pp. 346-349. (In Russ.) 
Cherlenok, E.A. 2001, "Chariots in the funerary rite (the beginning of the Late Bronze Age in the Eurasian steppes)", Vestnik molodyh uchenyh. Ser. Istoricheskie nauki, no. 1, pp. 22-29. (In Russ.)

Chechushkov I.V. 2011, "Chariots of the Eurasian steppes of the Bronze Age", Bulletin of Archeology, Anthropology and Ethnography, iss. 2(15), pp. 57-65. (In Russ.)

Chechushkov, I.V. 2013, The chariot complex of the Late Bronze Age of steppe and forest-steppe Eurasia (from the Dnieper to the Irtysh). Avtoref. dis. ... kand. ist. nauk. Moscow, 26p. (In Russ.)

Chechushkov,I.V., Epimakhov,A.B. "The chariot complex of the Ural-Kazakhstan steppes", Koni, kolesnicy i kolesnichie stepej Evrazii. Kollektivnaya monografiya ("Horses, chariots and charioteers of the Eurasian steppes. A collective monograph"). Yekaterinburg, 2010, pp. 182-229. (In Russ.)

Sternberg, L.Y. 1936, Prehistoric religion in the light of ethnography. Nauka, Leningrad, 571 p. (In Russ.)

Day, L.P. 1984, "Dog burials in the Greek world", American journal archaeology, vol. 88, no. 1, pp. 2132.

Kupriyanova,E., Epimakhov,A., \& Berseneva,N., Bersenev,A. 2017, "Bronze Age Charioteers of the Eurasian Steppe: A Part-time Occupation for Select Men?", Praehistorische Zeitschrift, no.92(1), pp.4065.

Makkay,J. 1996, “Mycenaean burial sacrifices and the origins of the Proto-Greeks", Atti e Memorie del Secondo Congresso Internazionale de Micenologia. Roma - Napoli, 1991, pp.777-784.

Narasimhan, V.M., Patterson, N., \& Moorjani, P., Rohland, N., Bernardos, R., Mallick, S., Lazaridis,, I., Nakatsuka, N., et al. 2019, "The formation of human population in South and Central Asia", Science, 365. Eaat7487, pp. 341. doi: 10.1126/science.aat7487.

Scott Littleton, C. "Some possible Indo-European themes in the Iliad", Myth and Law among the IndoEuropeans. Berkley, Los Angeles, London, 1970, pp. 229-246.

Vanderpool,E. 1959, "New letter from Greece", American journal archaeology, vol. 63, no. 3, pp. 279283.

Vermeule,E. 1979, Aspects of death in early Greek art and poetry. University of California Press, Berkeley, Los Angeles, London, 270 p.

Ward, D. "The separate function of the Indo-European Divine Twins", Myth and Law among the Indo-Europeans. Berkley, Los Angeles, London, 1970, pp. 193-202.

Wikander, S. 1957. "Nakula et Sahadeva”, Orientalia Suecana, vol. 6, pp. 66-96.

Zdanovich,D.G., Gayduchenko,L.L. "Sintashta burial sacrifice: The Bolshekaragansky cemetery in focus", Complex societies of Central Eurasia from the $3^{\text {rd }}$ to the $1^{\text {st }}$ Millenium BC: Regional specifics in light of global models, vol.I. Washington DC, 2002, pp. 202-231.

\section{Сведения об авторе}

Куприянова Елена Владиславовна, кандидат исторических наук, директор Учебно-научного центра изучения проблем природы и человека, Челябинский государственный университет, Российская Федерация, г. Челябинск. E-mail: dzdan@mail.ru, ORCID: 0000-0001-8842-9976

\section{Information About the Author}

Elena V. Kupriyanova, Ph.D. Head of the Educational and Scientific Center for the Study of the Problems of Nature and Man, Chelyabinsk State University, Russian Federation, Chelyabinsk. E-mail: dzdan@mail.ru, ORCID: https://orcid.org/0000-0001-8842-9976 